\title{
A Lagrangian perspective of the hydrological cycle in the Congo River basin
}

\author{
Rogert Sorí $^{1}$, Raquel Nieto ${ }^{1,2}$, Sergio M. Vicente-Serrano ${ }^{3}$, Anita Drumond ${ }^{1}$, and Luis Gimeno ${ }^{1}$ \\ ${ }^{1}$ Environmental Physics Laboratory (EphysLab), Universidade de Vigo, Ourense, 32004, Spain \\ ${ }^{2}$ Department of Atmospheric Sciences, Institute of Astronomy, Geophysics and Atmospheric Sciences, \\ University of São Paulo, São Paulo, 05508-090, Brazil \\ ${ }^{3}$ Instituto Pirenaico de Ecología, Consejo Superior de Investigaciones Científicas (IPE-CSIC), \\ Zaragoza, 50059, Spain \\ Correspondence to: Rogert Sorí (rogert.sori@uvigo.es)
}

Received: 3 March 2017 - Discussion started: 9 March 2017

Revised: 26 May 2017 - Accepted: 16 June 2017 - Published: 4 August 2017

\begin{abstract}
The Lagrangian model FLEXPART is used to identify the moisture sources of the Congo River basin (CRB) and investigate their role in the hydrological cycle. This model allows us to track atmospheric parcels while calculating changes in the specific humidity through the budget of evaporation minus precipitation. This method permits the annual-scale identification of five continental and four oceanic principal regions that provide moisture to the CRB from both hemispheres over the course of the year. The most important is the CRB, which provides more than $50 \%$ of the total atmospheric moisture contribution to precipitation over itself. Additionally, both the land that extends to the east of the CRB and the eastern equatorial South Atlantic Ocean are very important sources, while the Red Sea source is merely important in the $(E-P)$ budget over the CRB despite its high evaporation rate. The moisture-sink patterns over the CRB in air masses that were tracked forward in time from all the sources follow the latitudinal rainfall migration and are mostly highly correlated with the pattern of the precipitation rate, ensuring a link between them. In wet (dry) years, the contribution of moisture to precipitation from the CRB over itself increases (decreases). Despite the enhanced evaporative conditions over the basin during dry years, the vertically integrated moisture flux (VIMF) divergence inhibits precipitation and suggests the transport of moisture from the CRB to remote regions.
\end{abstract}

\section{Introduction}

The water that falls on a given area as precipitation may be supplied by local evaporation and/or transpiration. Alternatively, this water may have been advected from a remote terrestrial source or originated as evaporation from the oceans (Dirmeyer and Brubaker, 1999). In recent years, a great number of studies have focused on deepening our understanding of these issues, particularly the mechanisms of water vapour transport in the atmosphere and the identification of moisture sources. These issues are considered to be some of the major challenges in the atmospheric sciences (Gimeno, 2013). Several techniques and methods have been implemented to address these matters; a summary of the main strengths and weaknesses of each method was provided by Gimeno et al. (2012).

Some authors have investigated the sources of moisture for the entire continent of Africa (van der Ent et al., 2010; Gimeno et al., 2010, 2012) and specific regions such as the Sahel (Nieto et al., 2006; Salih et al., 2015; Keys et al., 2012, 2014), Ethiopia (Viste and Sorteberg, 2013), and the wider region of West Africa (Savenije, 1995; Eltahir and Gong, 1996; Druyan and Koster, 1989). Nevertheless, the Congo River basin (CRB) in the highly convective region of Central Equatorial Africa (CEA) is one of the least studied of the major global river basins (Alsdorf et al., 2016). Stohl and James (2005), who focused on several world river catchments such as the Congo, used the Lagrangian model FLEXPART 
over a period of 4 years (December 1999-November 2003) to diagnose the net $(E-P)$ budget, in which $(E)$ denotes evaporation and $(P)$ precipitation. However, the short timescale in this study was not sufficient to properly investigate the variability and other aspects of the hydrological cycle over the CRB. Gimeno et al. (2010) argued that the evaporation rate in tropical South Africa during the austral winter is so high that this region provides moisture for most of the precipitation over the Congo. According to van der Ent et al. (2010), the moisture that evaporates in East Africa is the main source of rainfall in the CRB.

More accurate results on the evaporative moisture sources for the CRB, together with their seasonal variations and mean contributions over a period of 25 years, are available online from the Center for Ocean-Land-Atmosphere Studies (COLA, 2017). These data were calculated by using a quasi-isentropic method, a Eulerian approach that was implemented in Dirmeyer et al. (2009), and the results highlighted that the main evaporative sources for precipitation lie within the basin itself, in addition to the land to the east of the basin along the Oriental African coasts, and the Atlantic and Indian oceans. However, the role of the CRB's moisture sources in other stages of the hydrological cycle and during extreme events in the basin remains unclear. Most studies that were based on instrumental records in Africa indicated that droughts have become more frequent, intense, and widespread over the last 50 years (Dai, 2013; Masih et al., 2014). The occurrence of drought is especially important in regions where economic activities greatly depend on water resources (such as the CRB) and particularly African nations that heavily rely on agriculture (Lobell et al., 2011a, b).

The objectives of this study are (i) to identify the main continental and oceanic moisture sources for the CRB from a Lagrangian perspective and determine their role, including that of the basin itself, in the total moisture contribution to precipitation over itself and (ii) to investigate drought and wet conditions in the CRB and their relationship to the atmospheric moisture supply.

\section{Study region}

The CRB is located in central-equatorial Africa, an important region of the continent that contains major rivers and dense forest (Fig. 1). With an approximate area of $3687000 \mathrm{~km}^{2}$ (Alsdorf et al., 2016), the basin includes several African countries: the Democratic Republic of the Congo (DRC), the People's Republic of the Congo, the Central African Republic, and portions of Zambia, Angola, Cameroon, and Tanzania (Chishugi, 2008). The Congo River (previously known as the Zaire) is over $4375 \mathrm{~km}$ long and is considered to be the fifth longest river in the world and the second longest in Africa after the Nile River (IBP, 2015). Its discharge shows a composite variability because of the sum of its tributaries (Laraque et al., 2001). With an annual discharge of $5000 \mathrm{~m}^{3} \mathrm{~s}^{-1}$ at its mouth, the Oubangui River is the sec-

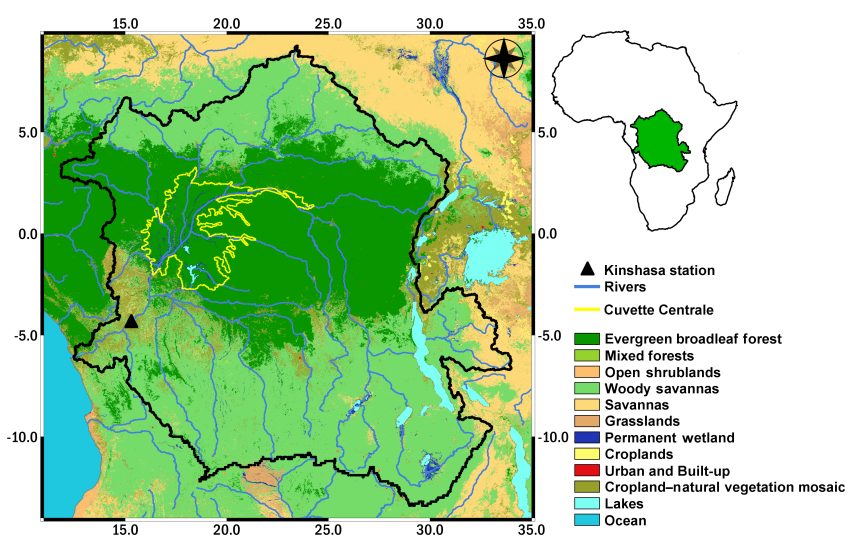

Figure 1. Geographic location of the Congo River basin, which shows the Kinshasa gauging station, the fluvial system, and the land use based on 10 years (2001-2010) (source: Broxton et al., 2014). The boundaries of the Cuvette Centrale are contoured in yellow (adapted from Betbeder et al., 2014).

ond most important tributary to the Congo River (mean flow $\left.41000 \mathrm{~m}^{3} \mathrm{~s}^{-1}\right)$ after the Kasai River $\left(8000 \mathrm{~m}^{3} \mathrm{~s}^{-1}\right)$ (Briquet, 1995).

The CRB comprises the second largest continuous rainforest in the world, covering an area of approximately 1.8 million $\mathrm{km}^{2}$. The high evaporation rate is comparable to that of the oceans and is one of the main features of the forests, which are extremely important for storing carbon, affecting the continental and global climate system, mainly through the water cycle (Haensler et al., 2013; Marquant et al., 2015; Wasseige et al., 2015). The basin basically consists of a central area that contains an immense forest swamp that is known as Cuvette Centrale, an immense depression at the centre of the basin where sediment accumulation has occurred since the Quaternary; alluvial deposits rest on thick sediments of continental origin, which principally consist of sands and sandstones (Kadima et al., 2011; Gana and Herbert, 2014) (Fig. 1). Here, the spatial distribution of forested wetland is controlled by the topography and the time and intensity of submersion, making this area the most extensive peatland complex in the tropics (Dargie et al., 2017). From a rainfall perspective, the Congolese central basin largely functions as a closed system of precipitation, on-site evaporation, and precipitation because of the topographic barrier around the Cuvette Centrale (Robert, 1946; Sorre, 1948). An immense elliptical body of water ( $3 \mathrm{~m}$ deep with a surface of $23 \mathrm{~km}^{2}$ and maximum water storage of $55 \times 10^{6} \mathrm{~m}^{3}$ ) called Lake Telé is located in the heart of the dense Congolese equatorial forest, where hydrological exchanges are almost exclusively vertical with very little lateral contribution from the surrounding swamp (Laraque et al., 1998). Furthermore, the basin contains several large, permanent open-water lakes, including Lake Tanganyika, the largest of the African rift lakes and the world's second largest by volume and depth (Coulter, 1991; Cohen et al., 1993). 
The central basin contains a dense humid evergreen forest, while mosaics of mixed forest, woody savannas, and savannas are present to the north and south (Marquant et al., 2015). The current distribution of different forest types strongly correlates with the annual rainfall and particularly with the length and severity of dry seasons (CARPE, 2005). The CRB's moist forests are the continent's main forest resource, containing extraordinary biodiversity (Ilumbe, 2006; SCBD-CAFC, 2009) that brings important economic benefits to approximately 60 million people in local communities (Nlom, 2011; Marquant et al., 2015). Unfortunately, the deforestation rate in the CRB varies between countries. Overall, the basin had a net deforestation rate of $0.09 \%$ between 1990 and 2000 compared to $0.17 \%$ between 2000 and 2005 (Tchatchou et al., 2015). In fact, satellite data showed a widespread decline in greenness in the northern Congolese forest over the past decade, which is generally consistent with decreases in rainfall, terrestrial water storage, and other related aspects (Potapov et al., 2012; Zhou et al., 2014; Hua et al., 2016) such as hydrological regimes (Laraque et al., 2001, 2013; Wesselink et al., 1996).

The air masses that originate from three permanent anticyclones to the northwest (Azores), southwest (St. Helena), and southeast (Mascarene) of the CRB converge along the Intertropical Convergence Zone (ITCZ), which separates the southerly low-level winds from the northerly winds, and the Inter-Oceanic Confluence Zone (IOCZ), which separates the westerly from the easterly winds in southern Africa (Samba and Nganga, 2012). Generally, two modes of circulation, namely, the Hadley circulation and the Walker circulation, control the movement of air masses and the climate in Central Africa, leading to non-uniform moisture convergence in the atmospheric column (Tsalefac et al., 2015; Pokam et al., 2012). Areas that are positively correlated with Congo convection are areas of the ascending arm of the Hadley cell (Matari, 2002), while the east-west oscillation of the Walker circulation cell modulates moisture advection from the Atlantic Ocean and the upward motion over the CRB (Matari, 2002; Lau and Yang, 2002). The rainfall-generation mechanisms are controlled by a zone of shallow depression systems in the CRB (Samba and Nganga, 2012), north-south ITCZ migration (Samba and Nganga, 2012; Alsdorf et al., 2016), mesoscale convective systems (MCSs) (Jackson et al., 2009), the African easterly jet, and the typical circulation of the Hadley cell (Nicholson, 2009; Pokam et al., 2012; Haensler et al., 2013).

\section{Data and methodology}

The drainage area of the CRB (Fig. 1) was defined by using geo-referenced watershed boundaries on a 30 arcsec resolution map (a HydroBASIN product of HydroSHEDS, or Hydrological data and maps based on SHuttle Elevation Derivatives at multiple Scales; Lehner and Grill, 2013). This map was used to obtain the spatial mask of the basin, which was later implemented in the computations.

The methodology in this study was based on the Lagrangian model FLEXPART, which was developed by Stohl and James (2004, 2005). This model enabled us to track air parcels backward and forward; thus, the model outputs were used to compute the gain and loss of humidity along trajectories of air particles that leave from and arrive in the CRB. The backward analysis was utilised to identify the moisture sources for the CRB, and the forward analysis was performed to obtain their climatological moisture supply and the relationship with the precipitation over the basin. This approach has been widely and successfully applied to study the atmospheric branch of the hydrological cycle (e.g. Stohl and James, 2004, 2005; Nieto et al., 2008; Gimeno et al., 2010, 2012; Chen et al., 2012; Viste and Sorteberg, 2013; Drumond et al., 2014).

In this method, the atmosphere is divided into $N$ evenly distributed particles or parcels, whose advection is described by Eq. (1):

$\mathrm{d} x / \mathrm{d} t=v[x(t)]$,

in which $x$ is the position of the parcel and $v[x(t)]$ is the interpolated wind speed in space and time. The gain (through evaporation from the environment $e$ ) or loss (through precipitation $p$ ) of specific humidity $(q)$ by each parcel is calculated following Eq. (2). Along with individual trajectories, $q$ fluctuations can occur for nonphysical reasons (e.g. because of $q$ interpolation or trajectory errors), a limitation that is partially compensated for by the presence of so many particles in an atmospheric column over the target area. Thus,

$(e-p)=m(\mathrm{~d} q / \mathrm{d} t)$

in which $m$ is the mass of a particle. Integrating over an area of interest produces the net effect of the moisture changes in all the particles in the atmospheric column and thus determines the surface freshwater flux, hereafter represented by $(E-P)$ (Stohl and James, 2004). In some regions, atmospheric moisture is not precipitated but merely flows through; in other regions, the convergence of moisture ensures that precipitation occurs (Pokam et al., 2012). A region is then considered a moisture source when $(E-P)>0$, and the net moisture budget of the tracked particles favours evaporation from the environment to the particles. The opposite occurs in moisture sink regions, i.e. the associated moisture budget favours moisture loss from the tracked particles to the environment. An analysis that is performed backward in time distinguishes the origin of the atmospheric moisture in the air masses over the $\mathrm{CRB}$, enabling us to identify the main oceanic and continental sources of moisture. This analysis was applied for 10 days, which is the average residence time of water vapour in the atmosphere (hereafter, we use $(E-P) i 10$; Eltahir and Bras, 1996; Numaguti, 1999).

The Lagrangian data that were used in this work were obtained from a FLEXPART v9.0 experiment that was executed 
on a global domain, in which the atmosphere was divided into approximately 2 million uniformly distributed particles. FLEXPART uses ERA-Interim reanalysis data (Dee et al., 2011), which are available at $6=\mathrm{h}$ intervals (00:00, 06:00, 12:00, and 18:00 UTC) at a resolution of $1^{\circ}$ at 61 vertical levels from 0.1 to $1000 \mathrm{hPa}$, with approximately 14 model levels below $1500 \mathrm{~m}$ and 23 below $5000 \mathrm{~m}$. This configuration is important because the transport of water vapour mainly occurs in the lower troposphere, which is clearly affected by the Earth's topography (Peixoto and Oort, 1992).

A threshold was used to ensure the selection of the most important annual moisture source regions for the CRB, which was defined by the value of the 90th percentile as calculated from the annual $(E-P)>0$ values after integration over the 10 days of transport. This value acted as a boundary to delimit regions where air masses gained more humidity during their journey to the CRB, representing the $10 \%$ of grid points with the highest positive $(E-P) i 10$ values on the map. This criterion was applied for similar purposes by Drumond et al. (2014, 2016a, b). The CRB itself is considered a source of moisture; thus, we could evaluate its role in the local $(E-P)$ budget. Tracking the air parcels forward from each of the delimited moisture sources enabled us to compare their moisture contributions to precipitation $((E-P)<0)$ over the CRB.

Precipitation data were obtained from the CRU TS v3.23 database (Harris et al., 2014) with a spatial resolution of $0.5^{\circ}$. The runoff and the vertically integrated moisture flux (northward and eastward) (VIMF) formed a portion of the ERAInterim reanalysis project (Dee et al., 2011), with a resolution of $1^{\circ} \times 1^{\circ}$ in latitude and longitude. The role of general circulation in the hydrological cycle can be clearly shown through maps of vertically integrated atmospheric moisture flow (Peixoto and Oort, 1992). The VIMF also enables readers to compare moisture transport under a Eulerian perspective (Drumond et al., 2014); consequently, these maps should support explanations of moisture budgets that are calculated by using FLEXPART.

The corrected monthly mean discharge of the Congo River as recorded at the gauging station of Kinshasa $\left(4.0^{\circ} \mathrm{S}\right.$, $15.3^{\circ} \mathrm{E}$ ) was provided by the Global Runoff Data Centre (GRDC). We used two state-of-the-art base datasets, namely, OAFlux and Global Land Evaporation Amsterdam Model (GLEAM) (Miralles et al., 2011), to estimate the actual evaporation over the moisture sources. The monthly ocean evaporation data were obtained from the OAFlux project, which uses surface meteorological fields from satellite remote sensing and reanalysis outputs from the NCEP and ECMWF models (Yu et al., 2008). The monthly evaporation from the land was estimated from GLEAM v2 data, which consider a set of algorithms, including transpiration, bare-soil evaporation, interception loss, open-water evaporation, and sublimation (Miralles et al., 2011), all of which are important because of the dense forests in the CRB.
Global datasets were selected because of documented gaps in the hydrological information for the CRB (Tshimanga, 2012). However, observational data series are available on the SIEREM website (Boyer et al., 2006), mainly to the north of the basin. In this work, the analysis covered the period 1980-2010 because of the availability of ERA-Interim since 1980 and the available river discharge data from the Kinshasa gauge station until 2010.

The methodology to quantify drought or wet conditions in the CRB was based on the Standardised Precipitation Evapotranspiration Index (SPEI), which is a multi-scalar drought index that considers the effects of both precipitation and atmospheric evaporative demand (AED) (VicenteSerrano et al., 2010). The SPEI for the CRB was calculated on timescales from 1 to 24 months by using precipitation and reference evapotranspiration (ETo) data from the CRU TS v3.23 dataset. The criterion of McKee et al. (1993) was used to identify years of severe and extreme drought and wet conditions (according to the SPEI threshold of \pm 1.5 ). The hydrological drought conditions were quantified at the gauging station of Kinshasa by using the Standardised Streamflow Index (SSI) (Vicente-Serrano et al., 2012).

\section{Results and discussion}

\subsection{Climatology: rainfall and runoff over the basin and the Congo River's discharge}

The annual cycle of precipitation over the CRB is depicted in Fig. 2. The most notable feature of the monthly patterns is the latitudinal migration of the maximum precipitation throughout the year, which leads to different seasonal patterns over the territory (Bultot, 1971; Chishugi, 2008). Based on previous results, Mahe (1993) defined four great climatic zones over the Congo Basin: the North (Oubangui River basin), where the influence of the North African continental air mass is prominent; the South (Kasai River basin), which is influenced by South African air masses; the eastern and southeastern areas of the basin (Lualaba River upper basin), which are influenced by the humid Indian Ocean air masses; and the Centre-West, where the climate is controlled by the Atlantic Ocean. In fact, the effect of rainfall on various sectors and its distribution throughout the annual cycle may be as important as the total annual rainfall (Owiti and Zhu, 2012). During January, February, and March, the southern half receives more precipitation, while April is a transitional month with maximum rainfall in the western-central and northeastern areas of the basin. From May to August, the rainfall pattern appears homogeneous, and the majority of the average precipitation occurs in the northern area, which coincides with the northward excursion of the ITCZ between February and August (Nicholson and Grist, 2003; Suzuki, 2011). From May to October, the northeastern CRB receives the highest rainfall, which favours the Oubangui catchment, a right-bank tributary of the Congo River that drains an area of $488500 \mathrm{~km}^{2}$ 


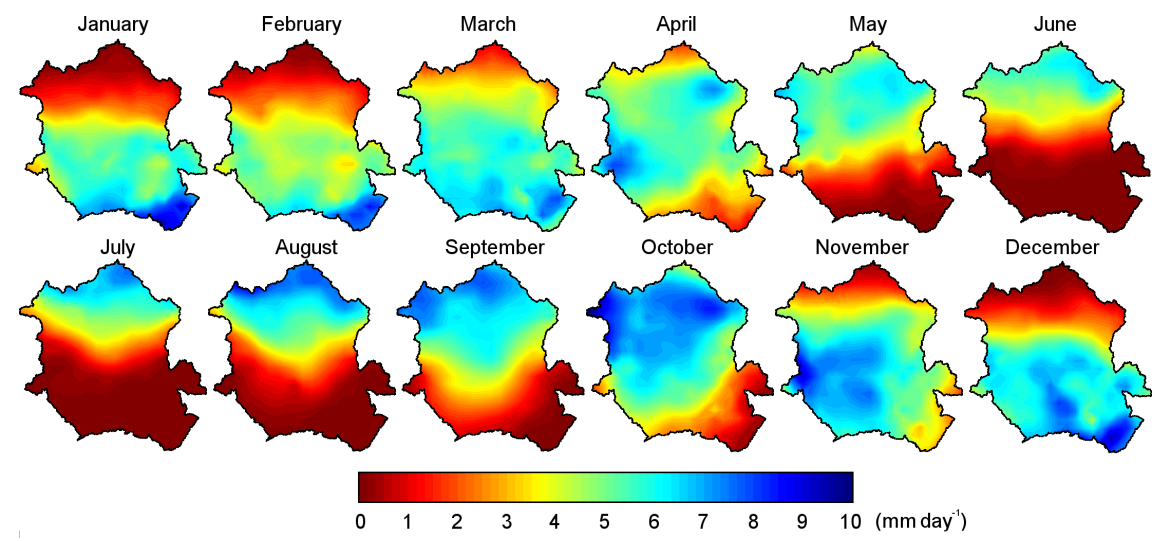

Figure 2. Monthly mean precipitation over the CRB for 1980-2010. The data are from CRU TS v3.23.

at the Bangui gauge station (Runge and Nguimalet, 2005). In September, the rainfall increases to the south and affects the centre of the basin, with the greatest extension in October. In November, the central and southwestern areas of the CRB receive more rainfall; December also exhibits an extension to the southeast (Fig. 2). The precipitation regime over the CRB is clearly differentiated by a latitudinal oscillation of maximum accumulated values, in accordance with several studies as reviewed by Alsdorf et al. (2016), and an interannual variability that is higher to the north and south than in the central units of the basin (Mahe, 1993).

The monthly average precipitation for the entire basin shows an annual cycle with two maximum peaks during March-April and October-December, with values above $4.5 \mathrm{~mm} \mathrm{day}^{-1}$ and each comprising 21 and $32.6 \%$ of the mean annual rainfall in the CRB, respectively (Fig. 3). During June and July, the average rainfall reaches its lowest level of around $2 \mathrm{~mm} \mathrm{day}^{-1}$. This cycle is similar to what was described by Washington et al. (2013), who compared the Congo's rainfall climatology through several datasets from reanalysis and ensemble models. However, these authors argued that the maximum rainfall in the basin occurs from March to May and from September to November, while the minimum occurs in June-August. These differences in monthly average precipitation may be caused by the areas that were used; these authors used a box region over equatorial West Africa, while we used the CRB's boundaries.

The mean annual cycle of runoff in the CRB (Fig. 3) follows the same annual cycle as rainfall, although the former is always lower, varying between maximum values of 3.0 and $3.5 \mathrm{~mm} \mathrm{day}^{-1}$ during November-March and minimum values below $1.5 \mathrm{~mm}_{\text {day }^{-1}}$ during July and August. The long-term distribution of precipitation and runoff over the African continent is almost the same (Siam et al., 2013), but the highest runoff values are concentrated in the heart of the equatorial forest along the middle Congo River branch (Alemaw, 2012), with these wetlands receiving the majority of their waters from upland runoff (Lee et al., 2011) and

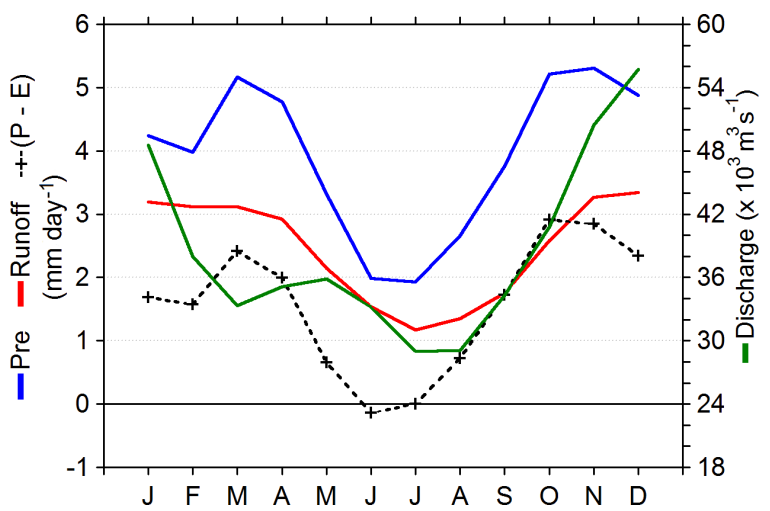

Figure 3. Annual cycle of precipitation, runoff, and $(P-E)$ in the CRB (left axis) and the Congo River's discharge (right axis). The data are from CRU, ERA-Interim, GLEAM, and the Global Runoff Data Center, respectively.

several large rivers that drain into the Congo in this middle section; the largest of these rivers is the Oubangui to the north of the Congo Basin (Harrison et al., 2016). The calculated inter-annual correlation between the two series (precipitation and runoff) over the CRB is high: $r=0.73$ (significant at $p<0.05$ ) and $r=0.72$ with a 1-month lag. Figure 3 shows that the runoff from March onward exhibits a 1-month lag compared to the precipitation. Generally, under steadystate conditions, the precipitation exceeds the evaporation (or evapotranspiration) over the land and the residual water runs off, resulting in the continental freshwater discharge into the oceans (Dai and Trenberth, 2002). This process also occurs in the CRB, where the monthly precipitation minus the actual evaporation seems to follow the same annual cycle as the precipitation (Fig. 3). June $(P-E)$ has a negative value, which means that the average evaporation exceeds the precipitation in the basin (as in Dai and Trenberth, 2002, and Siam et al., 2013).

The mean annual discharge of the Congo River is $38617.4 \mathrm{~m}^{3} \mathrm{~s}^{-1}$, which was calculated from the GRDC 
monthly discharge values at the Kinshasa gauging station in the period 1980-2010. According to the secular chronic of the hydro-pluviometric data (1903-2010) that were recorded at the Brazzaville gauge station close to Kinshasa, which was analysed by Laraque et al. (2013), the average flow of the Congo River from 1982 to 1994 was below the annual mean, followed by a period of stability from 1995 to 2010 . The long-term results of Mahe et al. (2013) suggested that the Congo River's runoff time series (at the Brazzaville station) followed no long-term trend (here, these authors referred to the runoff as the discharge) and that the minimum showed less inter-annual variability than the average or maximum.

The annual cycle of discharge (which is very similar to the precipitation and runoff) shows climatological maxima during November-December (Fig. 3), with values above $48000 \mathrm{~m}^{3} \mathrm{~s}^{-1}$, while the minimum in July and August is less than $30000 \mathrm{~m}^{3} \mathrm{~s}^{-1}$. However, one difference is seen during March, when high precipitation and runoff occur but the discharge is low. During the next few months, the precipitation and runoff decrease while the discharge increases, reaching a maximum in May. This lag should reflect both the required time for the surface runoff to reach the river mouth and the groundwater contribution (Dai and Trenberth, 2002; Dai et al., 2008; Marengo, 2005; Rwetabula et al., 2007; Sear et al., 1999), as documented by Materia et al. (2012), who used data that were recorded at the Brazzaville station approximately $400 \mathrm{~km}$ upstream of the river mouth. The direct relationship between the precipitation over the basin and the discharge has a correlation of 0.52 , which increases to 0.66 for a 1-month lag (both statistically significant at $p<0.05$ ), confirming the aforementioned lagged response. Bricquet (1993) noted that a translation of the stability of this hydrological regime is shown by a high (low) frequency of floods on similar dates in each year. Future climate projections (21st century), although uncertain, show a basinwide average increase in both rainfall and evaporation, but the total increase in rainfall tends to be higher than the increase in evaporation; the result in most scenarios is increasing runoff (Beyene et al., 2013). Nevertheless, Tshimanga and Hughes (2012) downscaled scenarios for the northern sub-basins of the Oubangui and Sangha rivers, in which more than a $10 \%$ decrease in the total runoff occurs because of the relatively little increase in rainfall and a consistent increase in potential evapotranspiration.

\subsection{Identification of the moisture sources}

In December, January, and February over the CRB, areas where $(E-P) i 10>0$ (moisture sources) are represented by reddish colours and are located over the northern half of the basin and over the river mouth (Fig. 4). Negative values $(E-P) i 10<0$ (sinks), which are portrayed in blueish colours, cover the southern CRB. Outside the boundaries of the basin, $(E-P) i 10>0$ values can be seen spread over the northeast of the continent, the Mediterranean Sea, the Red
Sea, the Arabian Sea, and the tropical eastern South Atlantic Ocean. Negative values are observed in the southeast of the basin, the tropical western Indian Ocean, and the equatorial Atlantic Ocean around the Equator. For these 3 months, the moisture convergence over central-equatorial Africa is between 0 and $20^{\circ} \mathrm{S}$, and a divergence belt of $0^{\circ}$ occurs to the north. The atmospheric divergence and convergence patterns are associated with high-pressure systems and low pressures at the Equator and in the ITCZ. The deep convection of the ITCZ depends on the contribution of water vapour from the surface moisture flux, which is supplied as surface latent heat flux, and the horizontal moisture flux in the lower free atmosphere (Suzuki, 2011). The VIMF identifies moisture that reaches the CRB from divergence zones over the Sahel and the Arabian Sea. Assessing the VIMF is extremely important because the seasonal variability in the spatial gradient of precipitation recycling in equatorial Central Africa is regulated by both the direction and strength of the moisture flux (Pokam et al., 2012).

In March, the $(E-P)$ pattern changes over the basin, with the establishment of intense moisture sinks to the centrewest. March seems to be a transitional month; in April, the $(E-P)$ pattern undergoes a more obvious change that is characterised by moisture loss over the northern half of the basin, a region that acts as a source in preceding months. However, the VIMF flows from east to west over the basin in both months, and the convergence and divergence fields of moisture flux are not that different from those in previous months, instead highlighting a decrease in the divergence over the Arabian Sea (Fig. 4).

Similar to in April, the $(E-P)$ budget over the basin from May to September is characterised by negative values in the northern half, which match the maximum precipitation rates for these months (see Fig. 2). From June to August (the driest months), these values are confined to the northern area of the basin, while an evaporative regime prevails over the rest of the CRB, which demonstrates the ability of FLEXPART to simulate moisture losses in the basin that are associated with convective precipitation and rainfall migration. Beyond the $\mathrm{CRB}$, the source areas $(E-P) i 10>0$ over the Arabian Sea diminish and the VIMF changes from its previously southwestward direction from May to September, which means that moisture transport from this region to Africa is no longer favoured. The $(E-P) i 10$ patterns are very similar to those of previous months for the other regions. During these months, the moisture sinks in the equatorial Indian Ocean are less intense than in previous months. At the same time, a latitudinal displacement of moisture convergence and divergence zones occurs over central-equatorial Africa; a joint analysis of the maximum precipitation and convergence of the VIMF provides a rough estimate of the position of the ITCZ (Žagar et al., 2011).

Locations where values of $(E-P) i 10>0$ are generally accompanied by moisture flux divergence. However, the Arabian Sea acts as moisture sink from May to October (blueish 

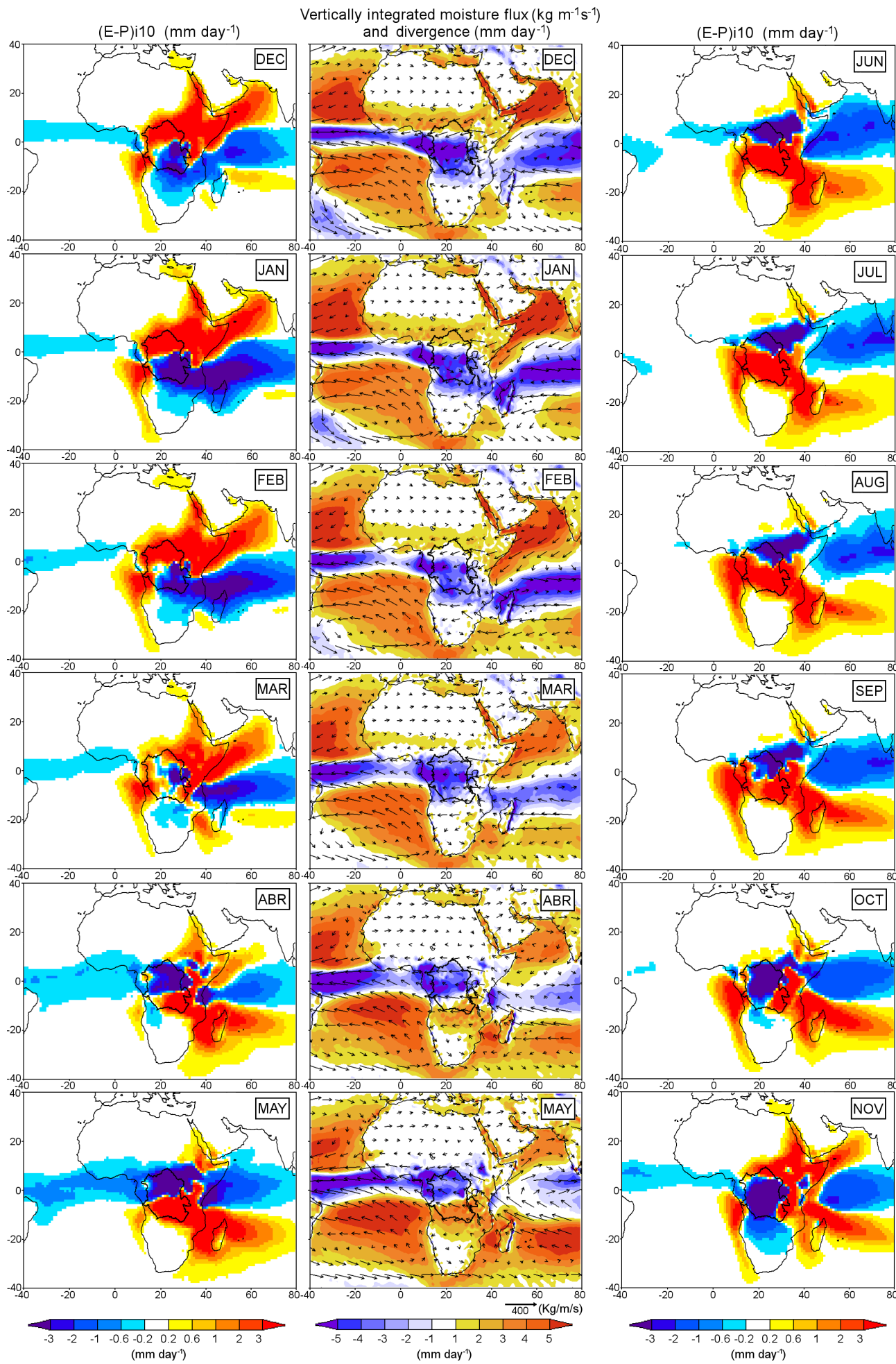

Vertically integrated moisture flux $\left(\mathrm{kg} \mathrm{m}^{-1} \mathrm{~s}^{-1}\right)$

and divergence $\left(\mathrm{mm}^{\mathrm{d}}\right.$ day-1)
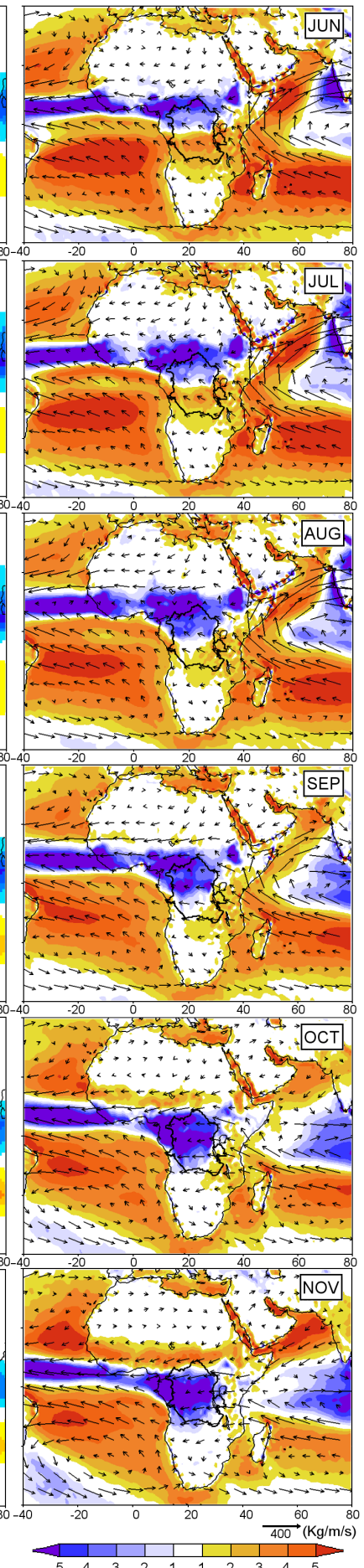

Figure 4. Monthly climatological $(E-P)$ values integrated backward over 10 days $\left(\mathrm{mm} \mathrm{day}^{-1}\right)$ alongside the vertically integrated moisture flux $\left(\mathrm{kg} \mathrm{m}^{-1} \mathrm{~s}^{-1}\right)$ and divergence-convergence (reddish-blueish colours) $\left(\mathrm{mm} \mathrm{day}^{-1}\right)$. Period: 1980-2010. 
colour in the left-hand panels); specifically, the VIMF shows an anticyclonic circulation over the Indian Ocean during June-September, which induces intense northeastward flow from the Arabian Sea to the Indian Peninsula and acts as an important moisture source for Indian monsoon rainfall (Levine and Turner, 2012).

The sink regions cover almost the entire CRB in October and November, when the southeastern Atlantic Ocean, the continental regions to the east and north of the basin, and the southwestern Indian Ocean all act as moisture sources. A transition in the scheme of the moisture source regions occurs in November, when $(E-P) i 10>0$ values appear once again over the Arabian Sea (Fig. 4). This result coincides with the beginning of the summer in the Southern Hemisphere and the decay of the Indian monsoon. The VIMF illustrates the moisture transport from the source regions to an area to the south of $0^{\circ}$ in central-equatorial Africa, which enhances the precipitation over the CRB in accordance with the southward movement of the ITCZ over Africa.

The climatological annual backward average of 10-day integrated $(E-P)$ from the CRB is presented in Fig. 5. This figure summarises the most important moisture sources for the CRB throughout the year. As discussed earlier, the boundaries of the moisture source regions were delimited by imposing the 90th percentile (p90) threshold of the annual $(E-P) i 10>0$ values. This result equates $0.43 \mathrm{~mm}$ day $^{-1}$, which is denoted in Fig. 5 by the dashed lines. Five continental (C) and four oceanic $(\mathrm{O})$ moisture sources were defined (Fig. 6). The five continental regions are as follows: central and northeastern Africa (C1), the equatorial-western section of the continent on both sides of the Equator and at the river mouth ( $\mathrm{C} 2$ to the north and $\mathrm{C} 3$ to the south), the eastern CRB along the coast of Africa from the north of Somalia and Ethiopia to approximately $20^{\circ} \mathrm{S}(\mathrm{C} 4)$, and the CRB itself. The four oceanic sources are in the Red Sea (O1), the Arabian Sea (O2), the eastern tropical equatorial South Atlantic Ocean along the coast of Africa (O3), and the tropical western Indian Ocean (O4). Such moisture source regions are not stationary, varying in intensity from year to year, and are expected to change in the future (Gimeno et al., 2013). In addition, their role may change given the high decadaland century-scale variability in the African climate (Masih et al., 2014). Nevertheless, these source regions provide insight into the mechanisms by which atmospheric moisture transport occurs toward central equatorial Africa. A combination of factors may influence the role of each source in the moisture influx into the CRB, such as the amount of evaporated water, the distance between each source and its target area, the atmospheric circulation, and the residence time of water vapour in the atmosphere.

A comparison with the evaporative moisture sources for the CRB from the quasi-isentropic method and online data (http://cola.gmu.edu/wcr/river/basins.html) confirms the importance of recycling in the $\mathrm{CRB}$, which matches our results in terms of the CRB retaining humidity from itself

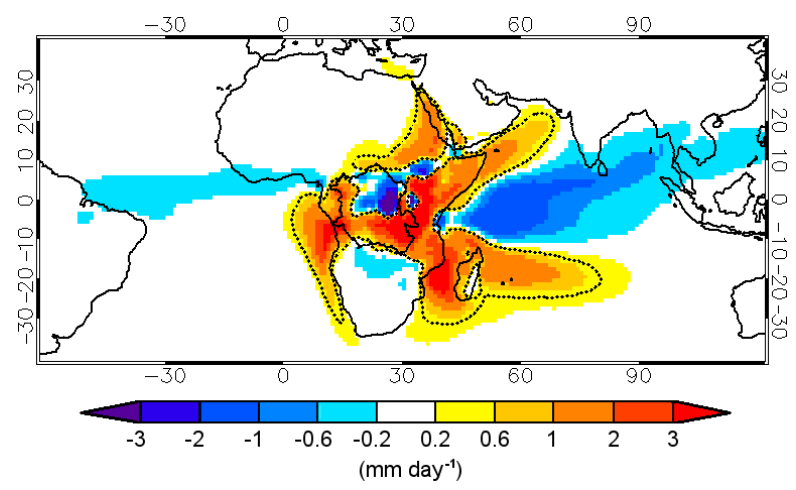

Figure 5. Annual mean $(E-P) i 10$ values backward-integrated over 10 days for the period 1980-2010. The dashed lines represent the boundaries of the moisture sources, which are defined as $p 90=0.4 \mathrm{~mm} \mathrm{day}^{-1}$.

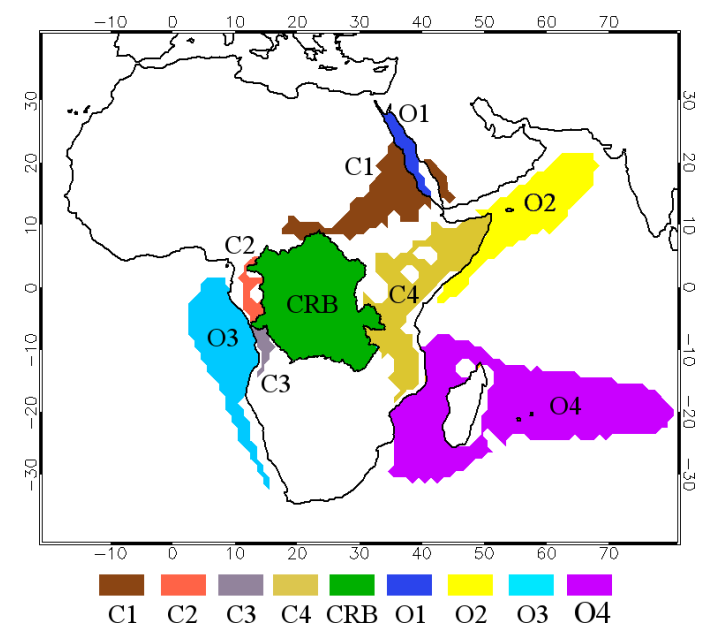

Figure 6. Continental moisture sources for the CRB: C1, C2, C3, $\mathrm{C} 4$, and the CRB itself; oceanic moisture sources: $\mathrm{O} 1, \mathrm{O} 2, \mathrm{O} 3$, and O4.

(Figs. 4, 5). Nevertheless, some differences exist on the annual scale: sections of the northern half of the basin act as moisture sinks (Fig. 5), while the aforementioned quasiisentropic climatology considers the entire basin to be an evaporative source. Another clear difference is the Indian Ocean: our results more clearly reflect the seasonal latitudinal migration of the evaporative regions over the year.

\subsection{Freshwater evaporation in the sources}

An analysis of the evaporation rate over the moisture sources may support our understanding of their role in the moisture uptake for the CRB over the year. Although the mean evaporation over a region that is considered to be a moisture source, quantified here by using GLEAM and OAFlux, can be high, its contribution to precipitation over the CRB might not be as high because this source could also be providing moisture for precipitation into other target regions. The geographical lo- 
Table 1. Mean annual evaporation rate over the sources. The data for the continent were obtained from GLEAM and those for the ocean from OAFlux.

\begin{tabular}{cccccccccc}
\hline & \multicolumn{8}{c}{ Evaporation rate $\left(\mathrm{mm} \mathrm{day}^{-1}\right)$} \\
\cline { 2 - 10 } Sources $\rightarrow$ & C1 & C2 & C3 & C4 & CRB & O1 & O2 & O3 & O4 \\
\hline & 1.0 & 2.5 & 1.6 & 1.5 & 2.4 & 4.6 & 1.1 & 0.71 & 4.7 \\
\hline
\end{tabular}

cation of the basin enables this area to receive moisture from the Atlantic and Indian oceans and from land regions around the basin, as Fig. 6 shows. Oceanic evaporation is very important if we consider that evaporation from the ocean surface equates roughly $86 \%$ of the total amount of water that is evaporated from the planet (Schmitt, 1995) and that the role of the oceans is decisive in continental precipitation (Gimeno et al., 2010). The mean annual evaporation from the sources is given in Table 1 by using data from OAFlux and GLEAM for the ocean and continental regions, respectively. On average, $\mathrm{O} 4$ and $\mathrm{O} 1$ are the most evaporative sources while $\mathrm{O} 3$ is the least evaporative. Among the continental sources, the most evaporative are $\mathrm{C} 2, \mathrm{CRB}$, and $\mathrm{C} 3$.

These sources are located in two different hemispheres and thus should have different annual evaporation cycles (Fig. 7). According to the FLEXPART backward experiment from the $\mathrm{CRB}$, monthly positive $(E-P) i 10$ values were calculated over each source (hereafter E-FLEX) to compare them with the yearly average evaporation at the sources. $(E-P)>0$ can be discounted after $(E-P)$ has been integrated without altering the general patterns of net precipitation by using a monthly or longer timescale (Castillo et al., 2014). Figure 7 displays both series for comparison alongside EGLEAM (evaporation data over continental sources) or EOAF (for oceanic ones) and E-FLEX. On the African continent, E-GLEAM is higher than E-FLEX in C1 from May to October (boreal summer), while the opposite occurs in the other months, indicating when this source becomes more efficient in providing moisture to the CRB (grey shaded areas in Fig. 7, C1). The next continental source is $\mathrm{C} 2$, which shows a higher land annual evaporative value (Table 1). In this source, the annual cycles of E-GLEAM and E-FLEX differ from those of $\mathrm{C}$. Over this region, the E-FLEX values are greater than the calculated local evaporation when using the GLEAM dataset during February and from June to October (grey shaded areas in Fig. 7, C2). Despite this local evaporation, E-GLEAM does not show any great variations over the year, varying from 2 to $3 \mathrm{~mm} \mathrm{day}^{-1}$. E-FLEX shows a bimodal cycle with a minimum in May $\left(\sim 0.3 \mathrm{~mm} \mathrm{day}^{-1}\right)$, when major local evaporation occurs, and a maximum in $\mathrm{Au}-$ gust $\left(\sim 4.2 \mathrm{~mm} \mathrm{day}^{-1}\right)$, when local evaporation is at its lowest. This behaviour illustrates that moisture can be available in the atmosphere (higher E-GLEAM values) but less humidity is taken up by air masses and then carried toward our target region (lower E-FLEX values). In this mechanism, the atmospheric circulation and the rainfall over the region must play a key role; E-FLEX could be lower than EGLEAM because of high $P$ values over the region. The grey shaded areas in Fig. 7 indicate months when the transport of moisture is favoured from the source to the CRB. Over the course of several days, an air parcel may undergo multiple cycles of evaporation and precipitation (Sodemann et al., 2008). After we integrated monthly data over 10 days, the E-FLEX values could be greater than the local evaporation. Nevertheless, C2 is a land region, where the recycling concept is most useful because moisture for evaporation is limited by precipitation, whereas the surface of oceans is clearly wet with or without rain (Trenberth, 1999). The C3 source, which is separated from $\mathrm{C} 2$ by the Congo River mouth, follows a similar annual evaporation cycle to $\mathrm{C} 2$ but with lower values $\left(<1 \mathrm{~mm} \mathrm{day}^{-1}\right)$ during June-October (Fig. 7, C3). In addition, the E-FLEX values are higher than E-GLEAM in February and July-September. In the months of MarchMay and November, C3 becomes less efficient at providing moisture to the CRB. For the continental source $\mathrm{C} 4$, the annual cycle of local evaporation (E-GLEAM) is similar to those of $\mathrm{C} 2$ and $\mathrm{C} 3$, but the moisture uptake by air masses that are tracked backward from the CRB (E-FLEX) over $\mathrm{C} 4$ is always greater than E-GLEAM (unless in February); thus, this source is very efficient in terms of moisture uptake for the CRB, which matches the results of van der Ent et al. (2014). For the CRB, the annual cycle of E-GLEAM is characterised by maximum values during December and March-May and minimum values in July-August (Fig. 7, CRB). In January-February, April-October, and December, E-FLEX is higher than E-GLEAM, which matches the decreasing precipitation over the basin (Fig. 3). This pattern is understandable because the moisture uptake (E-FLEX) over the basin itself must be favoured when the precipitation over the area decreases. Comparing the annual precipitation cycle in the CRB (Fig. 3) with E-GLEAM (Fig. 7) indicates the same annual cycle, but both sets of results show opposite behaviour from E-FLEX (Fig. 7, CRB). This relationship describes a scheme in which the precipitation and evaporation are strongly lineally related; in fact, evaporation as a source for precipitation over land depends on the availability of surface moisture, which in turn depends on the disposition of precipitation once it hits the ground (Trenberth, 1999). However, the moisture uptake is the opposite, determining when the source is more effective in providing moisture for itself, which is favoured when precipitation decreases. This relationship is not strictly interdependent because it could be 

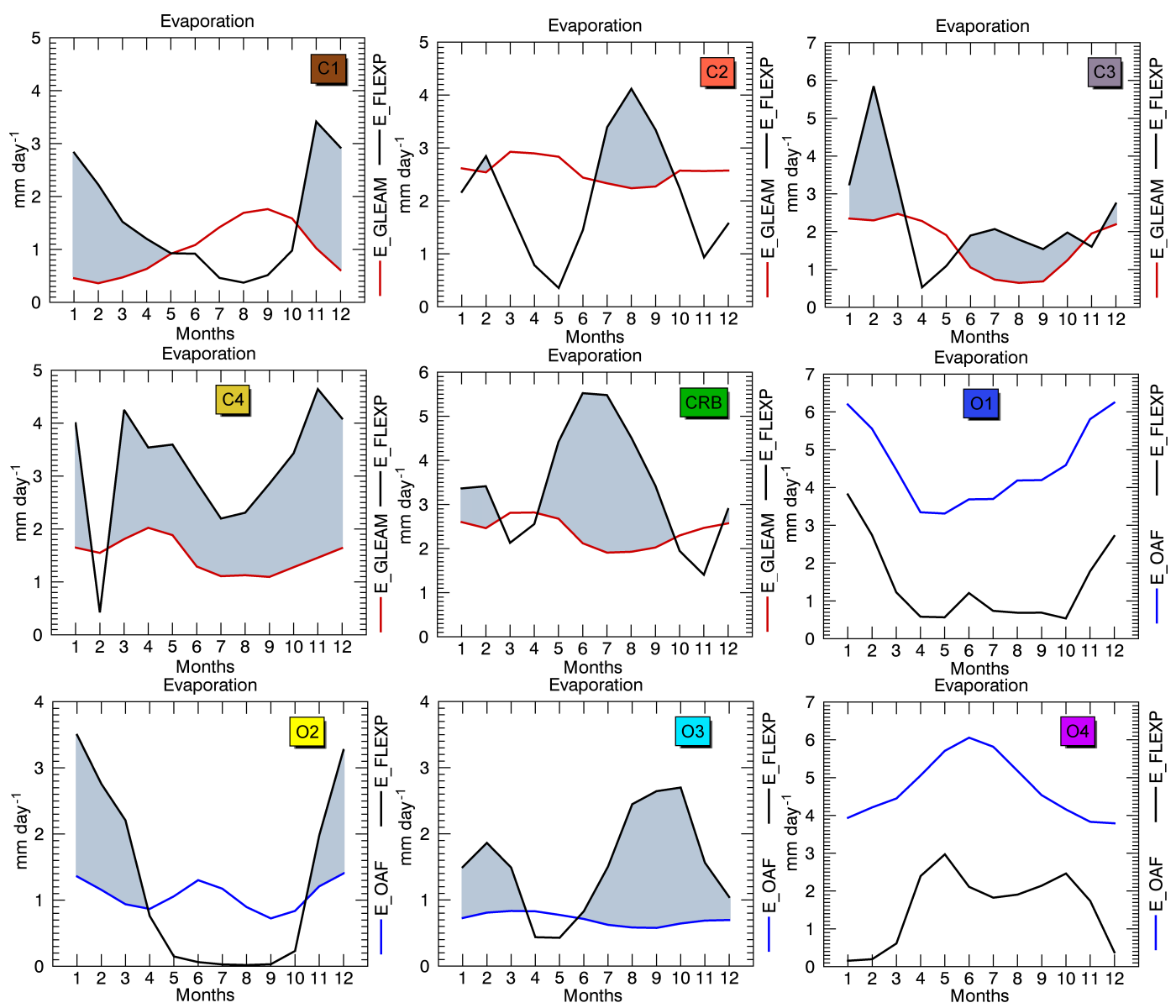

Figure 7. Monthly mean evaporation $\left(\mathrm{mm} \mathrm{day}^{-1}\right)$ in the continental (C) and oceanic (O) sources. The data are from GLEAM (red lines) and OAFlux (blue lines). E-FLEX: evaporation values over the sources from FLEXPART (black lines). The areas that are shaded in grey mark where E-FLEX > evaporation. Data period: 1980-2010.

modulated by moisture income from other sources or transported outside the boundaries of the target region (the basin).

In source O1, the mean annual E-OAF is $4.60 \mathrm{~mm} \mathrm{day}^{-1}$ (Table 1). This source is located in the Red Sea, where the oceanic evaporation rate is the highest in the world according to Abdulaziz (2012). After reviewing many studies, Sofianos et al. (2002) confirmed several differences in the mean annual evaporation rate for the Red Sea, but this value was estimated at around $2.06 \mathrm{~m}$ year $^{-1}\left(\sim 5.6 \mathrm{~mm} \mathrm{day}^{-1}\right)$. Figure 7 shows the annual evaporation cycle (E-OAF) in this source, which is characterised by higher values during the boreal winter months and minimum values in summer, which matches Bower and Farrar (2015). The monthly E-FLEX values over this source follow the same annual cycle as EOAF but with lower values. Despite being a high evaporative source, the moisture uptake from $\mathrm{O} 1$ to the air masses in transit to the CRB is less than what it must provide itself to the atmosphere, converting this area into a region that is not efficient in terms of the moisture supply to the CRB. In contrast, this area seems to be an important moisture source during December-February over continental areas to its north- east and during June-August to the remote area of the Indian Peninsula (Gimeno et al., 2010). The O2 source in the Arabian Sea shows two evaporation peaks during DecemberJanuary and June and two minima in April and September (Fig. 7). This cycle was also noted by Pokhrel et al. (2012) and Sadhuram and Kumar (1987), who showed that the maxima are related to strong winds and the minima are a result of low wind speeds and weak vapour pressure across the Arabian Sea. The moisture uptake over this source between April and October is almost insignificant, but the evaporation from OAFlux is greater; thus, this source is not efficient in delivering moisture to the CRB because this region contributes to the Indian monsoon during these months (Levine and Turner, 2012). The source in the Atlantic (O3) has the smallest monthly average evaporation rate among all the oceanic sources throughout the year $\left(<1 \mathrm{~mm} \mathrm{day}^{-1}\right)$ (Table 1), showing a negligible annual cycle. Materia et al. (2012) determined that the evaporation rate from the ocean surface is lower because a portion of this oceanic region is affected by the huge freshwater discharge of the Congo River, decreasing the sea surface salinity (SSS) and sea surface temperature 
(SST). However, E-FLEX is greater than E-OAF except during April and May, when the moisture uptake over this source is less than $1 \mathrm{~mm} \mathrm{day}^{-1}$. The moisture uptake has two peaks: one in February and the other in September-October. The last oceanic source is $\mathrm{O} 4$, which is the most evaporative and is characterised by a maximum average E-OAF in May-July $\left(>5.5 \mathrm{~mm} \mathrm{day}^{-1}\right.$ ) and a minimum at the beginning and end of the year (Fig. 7, O4). This behaviour matches the results of $\mathrm{Yu}$ (2007), who argued that evaporation in the Northern (Southern) Hemisphere intensifies during the boreal (austral) wintertime. The positive E-FLEX values over this source $(\mathrm{O} 4)$ are lower and quite different from the mean E-OAF during all months. On average, this source is not very efficient in supplying moisture to the CRB. The efficiency of a region that provides moisture for precipitation to a target area depends on the amount of evaporated water that reaches it and not just the initial evaporation rate. In this mechanism, we must highlight the importance of the atmospheric circulation patterns in determining the water vapour transport, the water vapour's residence time in the atmosphere, and moisture uptake from each source that is completely different from the evaporation.

\subsection{Moisture contribution from the sources: forward analysis}

Having identified the moisture source regions and their efficiency in providing moisture to air masses in transit to the $\mathrm{CRB}$, we determined the quantities and locations of the moisture loss over the CRB from those particles that leave each source by using forward tracking. For this purpose, a forward experiment with FLEXPART was used to integrate particles forward over 10 days. FLEXPART was used to compute the changes in $(E-P)$ by tracking air parcels with or without rain; in this case, we only computed the result for those particles that arrive in the CRB that lost humidity $(E-P) i 10<0$, hereafter called the moisture contribution.

The annual cycle of the percentage moisture contribution to precipitation from each source with respect to the total moisture contribution to the basin appears in Fig. 8 alongside the monthly mean precipitation over the CRB from CRU TS v3.23 data (Harris et al., 2014). The basin itself is the most important moisture source throughout the year, contributing more than $50 \%$ each month (green line) to the total moisture supply from all the sources to the basin. The contribution from each of the remaining continental and oceanic sources does not exceed $20 \%$ of the total. This result suggests the importance of moisture recycling over the basin, which differs from the result of van der Ent et al. (2010), who argued that the main source of rainfall in the Congo is moisture that evaporates over East Africa, particularly over the Great Lakes region. This result is probably a consequence of the methods that were used; their approach considered how much of the evaporated water returns as precipitation to the same region

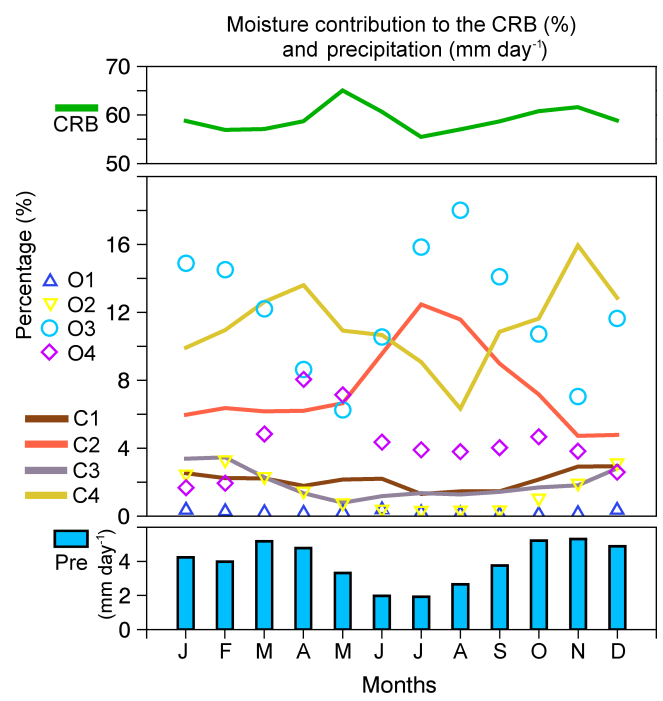

Figure 8. Monthly percent of moisture loss, which is calculated as $|(E-P) i 10<0|$ forward-integrated from each source over the CRB over 10 days of transport, and the monthly mean precipitation from the CRU datasets for the period 1980-2010.

(regional evaporation recycling) and how much of this water is advected out of the region.

The percentage of the moisture contribution to precipitation over the $\mathrm{CRB}$ is quite similar for the $\mathrm{C} 1$ and $\mathrm{C} 3$ sources, less than $4 \%$. $\mathrm{C} 2$ and $\mathrm{C} 4$ are the most important continental sources (after the CRB itself) that supply moisture to the CRB across the year; these sources are located to the east and west of the basin, respectively, and play opposite roles throughout the year. The moisture supply that was calculated for C4 from FLEXPART, $|(E-P) i 10<0|$, follows the annual precipitation cycle in the basin particularly well. The moisture contributions to the basin from $\mathrm{O} 1$ and $\mathrm{O} 2$ with respect to the total are less important than those from $\mathrm{O} 3$ and O4. The contribution from O3 increases and is thus important when the contribution decreases from the CRB itself, confirming the importance of moisture transport from the Atlantic Ocean. The contribution of moisture from $\mathrm{O} 3$ reaches a maximum in January-February and July-August (>14\%) when the precipitation rate decreases over the CRB (Fig. 3). The maximum monthly contribution from $\mathrm{O} 4$ in the Indian Ocean occurs in April-May $(\sim 8 \%)$.

We analysed the percentage of moisture that is supplied from land-based and oceanic sources to the total moisture inflow to the CRB for the period 1980-2010. The results confirm that close to or more than $80 \%$ of the total moisture contribution to precipitation over the basin during the year originates from land sources, with more than $50 \%$ of the total originating from the CRB itself (Fig. 9). Evaporation as a source for precipitation over land depends on the availability of surface moisture, which in turn depends on the disposition of precipitation once it hits the ground (Trenberth, 1999). According to Eltahir (1998), the soil mois- 
ture conditions over any large region should be associated with relatively large moist static energy in the boundary layer, which favours the occurrence of more rainfall. This hypothesis was also confirmed for West African monsoons by Zheng and Eltahir (1998). In this vein, van der Ent and Savenije (2011) quantified the spatial and temporal scale of moisture recycling independent of the size and shape of the region and found that approximately $70 \%$ of the precipitation in the centre of the South American continent is of terrestrial origin, as in many regions of Africa but specifically in the CRB, where strong moisture feedback occurs. Pokam et al. (2012) and Trenberth (1999) reported a higher recycling ratio (the fraction of rainfall from evapotranspiration and not from moisture that is advected to the target region) for CEA than what was obtained for the Amazon in Eltahir and Bras (1994) and Burde et al. (2006). As previously mentioned, the role of forests in the CRB is also fundamental because these areas sustain atmospheric moisture through evapotranspiration, which is of utmost importance for the region's water resources, particularly in the evergreen forest region (Matsuyama et al., 1994; van der Ent and Savenije, 2011). The key role of continental moisture sources has also been documented for monsoonal regions such as western Mexico (Bosilovich et al., 2003; Domínguez et al., 2008), South America (Drumond et al., 2014; Keys et al., 2014), and the Indian region (Misra et al., 2012; Pathak et al., 2015).

The annual role of the moisture sources that contribute to precipitation in the CRB is shown in Table 2 as the percentage of the total annual $|(E-P) i 10<0|$ amounts over the CRB. The CRB itself is responsible for $59.3 \%$ and is the most effective source, followed by $\mathrm{C} 4$ with $12 \%$ and $\mathrm{O} 3$ with $11.5 \%$. These three sources comprise $82.8 \%$ of the total moisture supply to the CRB throughout the climatological year. The remaining sources contribute $17.2 \%$ of the total precipitable moisture. The $\mathrm{O} 1$ source in the Red Sea is responsible for only $0.2 \%$.

To analyse the linear relationship, Table 3 shows the significant correlation values among the monthly series of evaporation, precipitation, runoff in the $\mathrm{CRB}$, river discharge at Kinshasa gauge station, $|(E-P) i 10<0|$ from each source over the CRB, and the total $|(E-P) i 10<0|$ from all the sources $(T)$. All the correlation coefficients are positive and statistically significant at $95 \%$, with the exception of those among $|(E-P) i 10<0|$ over the CRB from $\mathrm{C} 2$, the evaporation in the basin, and the Congo River discharge at the Kinshasa gauge station. As expected, the correlation is greater with precipitation than evaporation because $|(E-P) i 10<0|$ may be associated with rainfall over the CRB. In most of the cases, the initial correlation values with the evaporation and those from the rest of the variables decreased because of the lagged response of the hydrological system. This behaviour is best exhibited by the correlation with $|(E-P) i 10<0|$ over the CRB in the air masses that were tracked forward in time from the CRB itself and for the total contribution. According to the correlation values in Table $3,|(E-P) i 10<0|$ is bet-

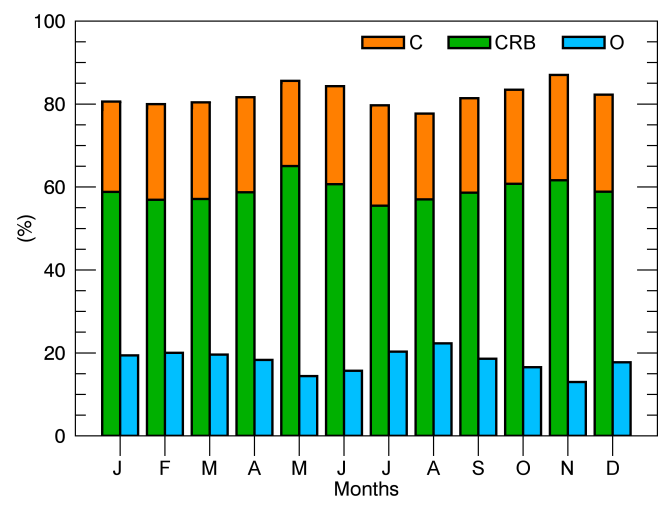

Figure 9. Monthly percentage moisture contributions to the CRB from continental sources (orange bars), the CRB itself (green bars), and oceanic sources (blue bars). The data are from FLEXPART for the period 1980-2010.

ter correlated with the discharge than the evaporation in the basin, except for the $|(E-P) i 10<0|$ values in the air masses from $\mathrm{O} 4$.

Figure 10 shows the spatial relationship between the moisture supply from the sources and the precipitation over the CRB. The mean seasonal $|(E-P) i 10<0|$ values over the CRB are plotted for December-February (DJF), MarchMay (MAM), June-August (JJA), and September-November (SON). Each map shows the correlation (bottom right) of these patterns with the respective climatological precipitation patterns over the basin (not shown).

The moisture sinks for the air masses from $\mathrm{C} 1$ to the CRB during DJF are more intense $\left(\sim 1.5 \mathrm{~mm} \mathrm{day}^{-1}\right)$ along a belt in the central-northern section of the basin that extends beyond this area to the south (Fig. 10). In MAM, the maximum moisture loss moves northward and almost disappears altogether in JJA, while the moisture loss in SON covers the entire CRB with major sinks in the northern half, which matches the high observed rainfall during these months (see Fig. 2). For SON, the best correlations were those between the $|(E-P) i 10<0|$ patterns from $\mathrm{C} 1$ and the precipitation over the CRB $(r=0.50)$. From $\mathrm{C} 2$, whose sources are located to the west of the $\mathrm{CRB}$, the greatest moisture contribution occurs over the west of the basin. In MAM and JJA, the $|(E-P) i 10<0|$ patterns are observed over the northern half, and the best correlation was obtained for JJA $(r=0.63)$. Contrary to what occurs with moisture loss over the basin from $\mathrm{C} 2$, the greatest moisture sinks over the CRB for air masses that were tracked forward from $\mathrm{C} 3$ are mostly positioned to the southwest (best observed for SON and DJF). In MAM and JJA, the sinks are mainly located in the northern half of the basin. For C4 (located to the east of the CRB), the sinks over the CRB decrease in intensity from east to west (the eastern areas show the most intense sinks, $>6 \mathrm{~mm} \mathrm{day}^{-1}$ ). In southern equatorial Africa and specifically in the CRB region, the precipitation pattern provides a mech- 
Table 2. Moisture contribution from the sources to the CRB (\%).

\begin{tabular}{rrrrrrrrrr}
\hline & \multicolumn{1}{c}{$(E-P) i 10<0$ in $\%$} \\
\cline { 2 - 10 } Sources $\rightarrow$ & C1 & C2 & C3 & C4 & CRB & O1 & O2 & O3 & O4 \\
\hline & 2.3 & 6.8 & 2.0 & 12.0 & 59.3 & 0.2 & 1.8 & 11.5 & 4.1 \\
\hline
\end{tabular}

Table 3. Significant monthly correlation $(p<0.05)$ between the precipitation from the CRU, runoff from ERA-Interim, river discharge from the GRDC and evaporation from GLEAM or OAFlux, and forward-integrated $|(E-P) i 10<0|$ series with FLEXPART from the sources over the CRB, with the total $|(E-P) i 10<0|$ amount $(T)$. Period used: 1980-2010.

\begin{tabular}{lrrrrrrrrrr}
\hline & $\mathrm{C} 1$ & $\mathrm{C} 2$ & $\mathrm{C} 3$ & $\mathrm{C} 4$ & $\mathrm{CRB}$ & $\mathrm{O} 1$ & $\mathrm{O} 2$ & $\mathrm{O} 3$ & $\mathrm{O} 4$ & $T$ \\
\hline Evaporation & 0.35 & & 0.35 & 0.36 & 0.37 & 0.35 & 0.43 & 0.14 & 0.35 & 0.36 \\
Precipitation & 0.60 & 0.53 & 0.65 & 0.77 & 0.80 & 0.36 & 0.58 & 0.60 & 0.58 & 0.83 \\
Runoff & 0.66 & 0.43 & 0.72 & 0.69 & 0.75 & 0.59 & 0.73 & 0.59 & 0.43 & 0.75 \\
Discharge & 0.49 & & 0.59 & 0.53 & 0.54 & 0.47 & 0.55 & 0.33 & 0.12 & 0.53 \\
\hline
\end{tabular}

anism of atmospheric communication between Africa's eastern and western coasts; these two equatorial regions are generally treated as climatically separate units (Dezfuli et al., 2015). As expected, the $|(E-P) i 10<0|$ pattern is more intense during SON and DJF (the rainiest months). The correlations vary between 0.36 and 0.43 , all of which are significant at $p<0.05$. Throughout the year, the CRB is the most important moisture source for itself (Fig. 9), which is confirmed by the intensity of the values in the $|(E-P) i 10<0|$ patterns (Fig. 10). In DJF and SON, the greatest moisture sinks $\left(>12 \mathrm{~mm} \mathrm{day}^{-1}\right)$ cover the majority of the centre and south of the basin. In MAM and JJA, these sinks are similar to the other sources. The correlation of these patterns with the spatial precipitation was the highest $(r>0.63)$.

We previously discussed how the oceanic source O1, despite being an important evaporative region, is not an effective moisture source for precipitation over the CRB. This fact can also be seen in the $|(E-P) i 10<0|$ pattern over the CRB in Fig. 10, in which the values are low and oscillate around 0 to $0.5 \mathrm{~mm} \mathrm{day}^{-1}$. The pattern also reflects the north-south variability in the precipitation over the year. The greatest moisture contribution from the $\mathrm{O} 2$ source in the Arabian Sea occurs in the eastern and northeastern areas of the basin, except in JJA, when the pattern is confined to the northwest and the moisture loss is lower. The $\mathrm{O} 3$ source in the eastern tropical Atlantic Ocean is the most important oceanic source for the CRB, as shown in Table 2. In DJF, the major moisture sinks are over the southwest of the basin. In MAM and JJA, the moisture loss is mainly over the central and north of the basin. In SON, this loss is to the east. These patterns show a good correlation with the rainfall's spatial distribution $(r>0.43)$. The greatest moisture contribution from $\mathrm{O} 4$ in the western Indian Ocean during DJF occurs over the south and along a longitudinal belt in the centre of the basin in MAM; in JJA, the largest contribution can be detected over the northern area of the basin. During SON, when the moisture loss from $\mathrm{O} 4$ covers practically the entire territory, with the highest loss over the east, the correlation with the precipitation pattern is negative $(r=-0.18)$. The highest precipitation for these months shows maxima over the northern and western areas (Fig. 2), which explains the negative correlation.

A common characteristic of the $|(E-P) i 10<0|$ patterns is that the most intense values are generally located near the moisture sources, as is clear for the contributions from $\mathrm{C} 2$, $\mathrm{C} 3, \mathrm{O} 3, \mathrm{O} 4$, and the CRB itself. The geographic location of the continental sources around the CRB and the dominant atmospheric circulation are the key factors that make this result possible.

\subsection{Role of moisture sources during severe dry and wet periods in the CRB}

We now consider the characteristics of the extreme hydrological conditions in the CRB. CEA has experienced a long-term drying trend over the past 2 decades (Diem et al., 2014; Zhou et al., 2014). The rainfall trend from 1951 to 1989 toward central Africa is initially much less clear near the Atlantic Ocean and then becomes more intense toward the interior of the continent (Olivry et al., 1993). This pattern was also noted by Hua et al. (2016) for CEA, who obtained a trend of $0.21 \mathrm{~mm} \mathrm{day}^{-1}$ per decade $(p<0.01)$ for the period 19792014 by utilising precipitation data from the Global Precipitation Climatology Project (GPCP).

The temporal evolution of the 1- and 12-month SPEI series for the $\mathrm{CRB}$ shows dry conditions during the periods 1980-1985, 1992-1998, and 2004-2006 (Fig. 11a, b). The prevalence of wet conditions can be seen from 1985 to 1991 and from 2007 to 2010. Hua et al. (2016) have documented consistently strong negative anomalies since the 1990s for CEA from April to June, and these were primarily related to SST variations over the Indo-Pacific seas from the enhanced and westward-extending tropical Walker circulation. These 


\section{$|(E-P) i 10<0|$ from:}

\section{Continental sources}

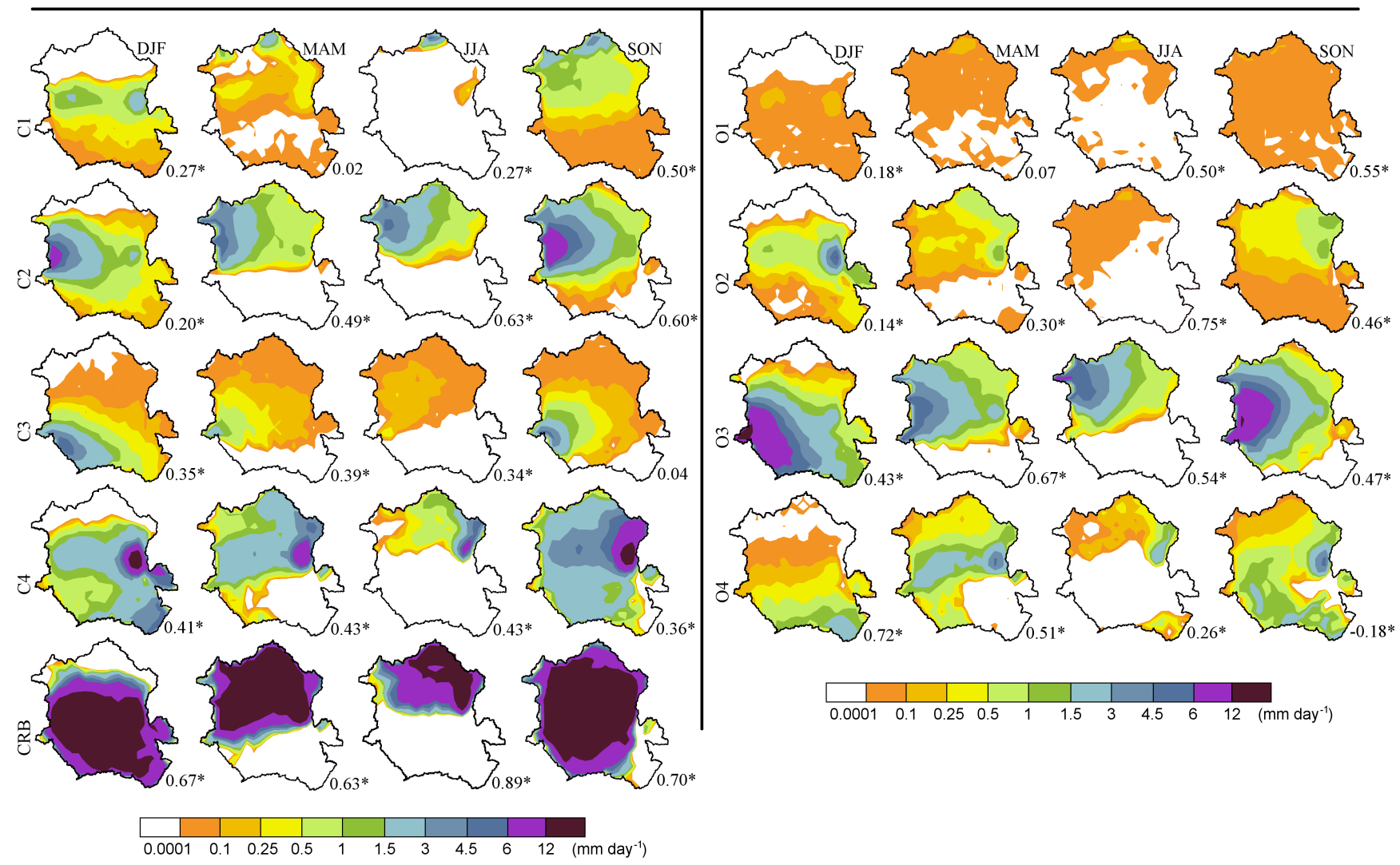

Figure 10. Seasonal mean $|(E-P) i 10<0|\left(\mathrm{mm} \mathrm{day}^{-1}\right)$ integrated forward from the moisture sources over the CRB for December-February (DJF), March-May (MAM), June-August (JJA), and September-November (SON). The number in the bottom-right corner of each plot indicates the correlation with the mean precipitation pattern (asterisks indicate significant values at $p<0.05$ ). Period: 1980-2010.

anomalies are also consistent with the weakened ascent over central Africa from the reduced low-level moisture transport. The hydrological drought conditions for the Congo River according to the Kinshasa gauge station records show temporal consistency with climate drought conditions in the basin (Fig. 11c).

We calculated the monthly correlations in the total moisture contribution to the basin $|(E-P) i 10<0|$ (summed from all the sources), runoff, and SSI for the 1- to 24-month SPEI timescales (Fig. 12) to investigate any possible temporal relationships. The significance of the correlation threshold was set at $p<0.05$. The correlations between the monthly values of $|(E-P) i 10<0|$ and SPEI show significant and high values for all months (Fig. 12a) for short SPEI timescales. The relationship is positive and statistically significant from January to March within the 24 SPEI timescales. During low-rainfall climatological months in the basin, especially in June, July, and August, the correlations are the lowest and even negative after the SPEI4 and SPEI5 timescales and generally remain so until the end. This result indicates negative feedback that may reflect the increased evapotranspiration that modulates the SPEI. As the months advance and the period of less rain ends, the correlations increase and become positive and significant from October to December from the first SPEI temporal scales until SPEI12. In these months, the correlations are the lowest and become negative for the major SPEI temporal scales, as shown in Fig. 12a. However, these correlations change for January and February, which exhibit positive correlations for all SPEI timescales and show a lag of approximately 1 month for the SPEI to reflect the recovery of wet conditions in the CRB.

In Fig. 12b, the surface runoff seems to strongly depend on SPEI for both shorter and longer temporal scales from January to April. Afterward (May-July), negative correlations appear after SPEI6 (Fig. 12b). The correlations also increase when the rainfall increases over the basin from July onward (Fig. 3). Here, we observe the same relationship between $|(E-P) i 10<0|$ and SPEI, but higher correlations were obtained. Correlations between SSI from the Kinshasa gauge station's discharge and SPEI (1-24 months) show that the evolution of the hydrological conditions is consistent with the meteorological rainfall deficit (excess) state over the 


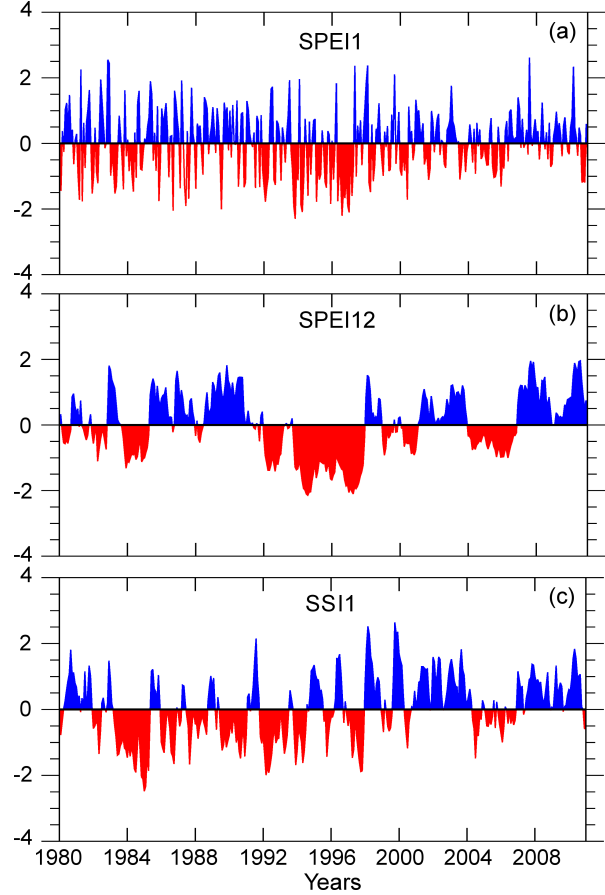

Figure 11. Time evolution of the SPEI in the Congo River basin after 1 (a) and 12 months (b) and the Standardised Streamflow Index (SSI) (c) that was computed for the Congo River's discharge. Period: 1980-2010.

basin (Fig. 12c). In particular, the strongest and most significant correlations were found from SPEI5 to SPEI7 from January to May, with a maximum in April; this result suggests the most appropriate timescales when identifying hydrological droughts (according to the Congo River's discharge at the Kinshasa gauge station) in terms of its relationship with the computed SPEI values for the entire CRB. The correlations from May to July, when the precipitation and discharge are the smallest (Fig. 3), are negative for the initial SPEI temporal scales, which suggest a time response of 2 or 3 months to reflect SPEI changes in river discharge.

We selected a few years affected by severe and extreme conditions to investigate the role of the moisture sources during drought and wet conditions in the CRB. For this purpose, SPEI values at the 12-month timescale for December were used to diagnose the status of the water balance throughout each year. Moreover, long drought timescales are generally used to assess streamflow droughts (Svoboda et al., 2012). On this timescale, we should represent the water balance in a region where the precipitation climatology is dictated by latitudinal migration across the Equator over the year, such as what occurs in the CRB.

During the period 1980-2010, the years 1995 and 1996 were characterised by severe (SPEI12_December $=-1.69$ ) and extreme (SPEI12_December $=-2.06$ ) drought conditions, respectively, while 1982 was characterised as severely wet $($ SPEI12_December $=1.68)$. Figure 13 shows the mean annual contribution (average over the number of grid points of the basin) from all sources and the $|(E-P) i 10<0|$ anomaly for each event. In 1982 (Fig. 13a), the most important moisture contributions are from the basin itself $\left(\sim 12.0 \mathrm{~mm} \mathrm{day}^{-1}\right), \quad \mathrm{O} 3 \quad\left(\sim 2.8 \mathrm{~mm} \mathrm{day}^{-1}\right)$, and $\mathrm{C} 4$ $\left(\sim 2.7 \mathrm{~mm} \mathrm{day}^{-1}\right)$. The $|(E-P) i 10<0|$ anomalies from all the sources are positive but are particularly high for the basin itself $\left(1.8 \mathrm{~mm} \mathrm{day}^{-1}\right)$. In 1995 and 1996 (Fig. 13b and c), the greatest moisture loss continues to be that from the air masses from the CRB itself, the oceanic source $\mathrm{O} 3$, and the continental source $\mathrm{C} 4$. However, when the anomalies were analysed, all the sources showed negative values; thus, the moisture support was less than the average conditions for the entire period. In 1995, the deficit in the contribution from the CRB and $\mathrm{O} 4$ is highlighted. Hua et al. (2016) described how an increase in subsidence across the western edge of the Indian Ocean (O4) and a decrease in convection over the CRB led to a reduction in moisture transport and rainfall across CEA. In 1996, a year that was characterised by extreme drought conditions, the negative anomaly in the moisture contribution to precipitation from all the sources remains, but the value that was computed for the basin was higher than in 1995. These results explain a mechanism in which the CRB is more (less) efficient in providing moisture for precipitation over itself during wet (dry) periods.

To clarify these results, we calculated the $|(E-P) i 10<0|$ (moisture contribution) and $(E-P) i 10>0$ (moisture uptake) anomalies in air masses that were tracked forward and backward in time, respectively, from the CRB for the 3 years under study. We utilised FLEXPART and obtained the $(E-P)$ budget but not the exact recycling, which computes the amount of precipitation that evaporates and falls again within the same region. Additionally, we calculated the anomaly of the VIMF to check the dynamical conditions that were favourable to the convergence-divergence of moisture flux.

In 1982, which was a severely wet year, higher positive $|(E-P) i 10<0|$ anomalies were observed in the northern half of the CRB, but mostly negative values were observed in the southern half (Fig. 14a). This pattern is clearly opposite to that for the same year in the $(E-P) i 10>0$ anomalies for the backward experiment (Fig. 14d), which explains the strengthening role of the southern half of the basin as a moisture source and mainly favours moisture loss over the northern CRB's evergreen forests. The VIMF anomalies support this result: negative values that identify convergence are observed over the northern half of the CRB, while positive anomalies that indicate divergence are observed in the southern half (Fig. 15a). Recycling supposedly decreases during wet periods, but Pathak et al. (2014) described how monsoons enhance the soil moisture and vegetation cover in the Indian region, increasing evapotranspiration and recycled precipitation. Additionally, a positive feedback was previously described by Bosilovich et al. (2003) and Domínguez et al. (2008) for the North American Monsoon region. Ad- 

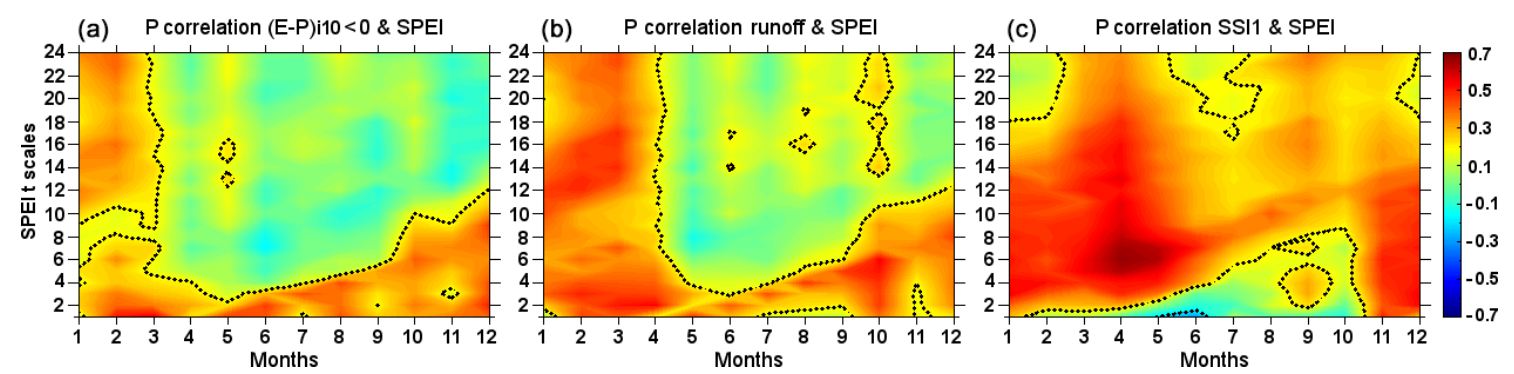

Figure 12. Monthly correlations among $|(E-P) i 10<0|(\mathbf{a})$, runoff (b), and SSI (c) from SPEI1 to SPEI24 in the Congo River basin. The dotted lines represent significant correlations at $p<0.05$
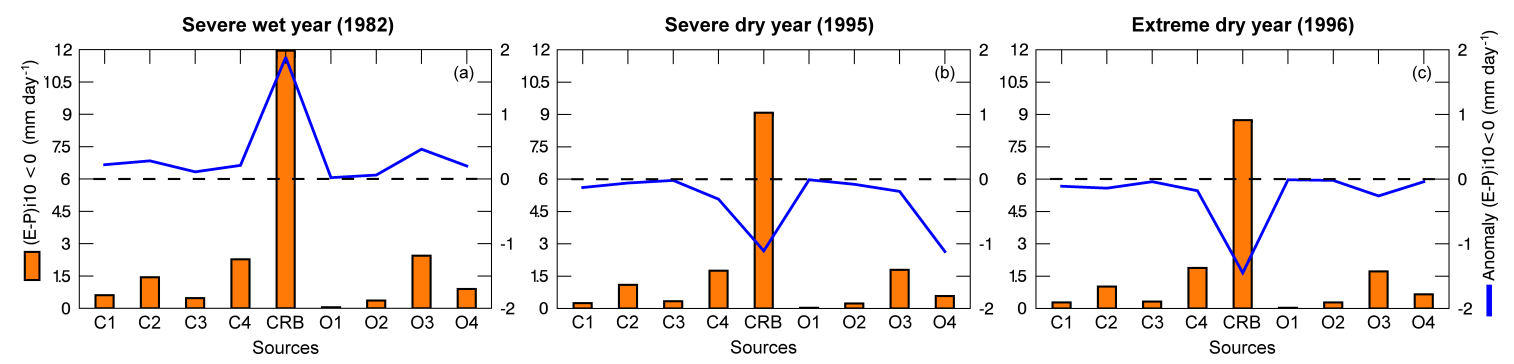

Figure 13. Mean annual moisture contribution from the sources to the CRB (orange bars) in 1982 (severe wet conditions, (a) 1995 (severe dry conditions, (b) and 1996 (extreme dry conditions, (c) alongside the corresponding anomaly (blue line).

ditionally, when the tropical rainbelt shifts northward during boreal summer months, the evergreen forest in the CRB rapidly becomes active because of the onset of the rainy season, increasing the evapotranspiration (Matsuyama et al., 1994). In 1982, both the evaporation and precipitation may have increased in the northern half of the CRB, with the latter increasing to a much greater degree, thus affecting the $(E-P)$ budget.

The Oubangui Basin in the northeastern CRB should have benefited in 1982 because of positive $|(E-P) i 10<0|$ anomalies, which favour precipitation in the northern CRB. A decrease in runoff throughout the Oubangui Basin coincides with a decrease in rainfall with a time lag of 3 years, which can be explained by the sponge-like functioning of the drainage basin, where inter-annual variability is less important for runoff than for the rainfall series (Orange et al., 1997). An important finding of these authors was that the maxima and minima of the annual rainfall did not completely coincide with extreme flow events; the year 1982 was a severely wet year with positive $|(E-P) i 10<0|$ anomalies over the northern half of the basin, including the Oubangui Basin. According to the results of Orange et al. (1997) and Laraque et al. (2013), the Oubangui Basin remained in a drought phase from 1982 to 2010 as the Congo returned to a phase of stability.

In 1995, which was a severely dry year, negative $\mid(E-$ $P) i 10<0 \mid$ anomalies covered the majority of the basin (Fig. 14b) and were more intense over the western and northern regions. In the backward analysis, these areas exhib- ited positive $(E-P) i 10>0$ anomalies (Fig. 14e) and positive VIMF anomalies, indicating the prevalence of divergence (Fig. 15b). In 1996, which was an extremely dry year, the mechanism was the same as in 1995 , but negative $|(E-P) i 10<0|$ anomalies occurred in almost the entire basin alongside the positive $(E-P) i 10>0$ anomalies. Trenberth and Guillemot (1996) discussed the importance of land-surface feedbacks in the 1988 drought and 1993 flood in the United States, while Dirmeyer and Brubaker (1999), Bosilovich and Schubert (2001), and Domínguez et al. (2006) agreed that 1988 had a higher recycling ratio than 1993 . The CRB exhibited positive $(E-$ $P) i 10>0$ anomalies during the dry years of 1995 and 1996, indicating moisture uptake by the atmosphere, which surely occurred because the evapotranspiration was enhanced and precipitation decreased. However, the prevalent divergence of the VIMF (Fig. 15b and c) did not favour moisture loss over the basin, which must have been transported outside, suggesting the role of the CRB itself as a moisture source for remote regions. A more detailed analysis should be performed in future works to determine the role of forests during drought conditions in the CRB. Figure 11c indicates that the lowest SSI values for the Kinshasa gauge station's discharge data occurred after 1995 and 1996 because of the lag period for precipitation, runoff, and underground water to feed rivers.

An important feature for 1982, 1995, and 1996 is that anomalies of moisture uptake and moisture contribution in air masses that were tracked backward and forward in time 

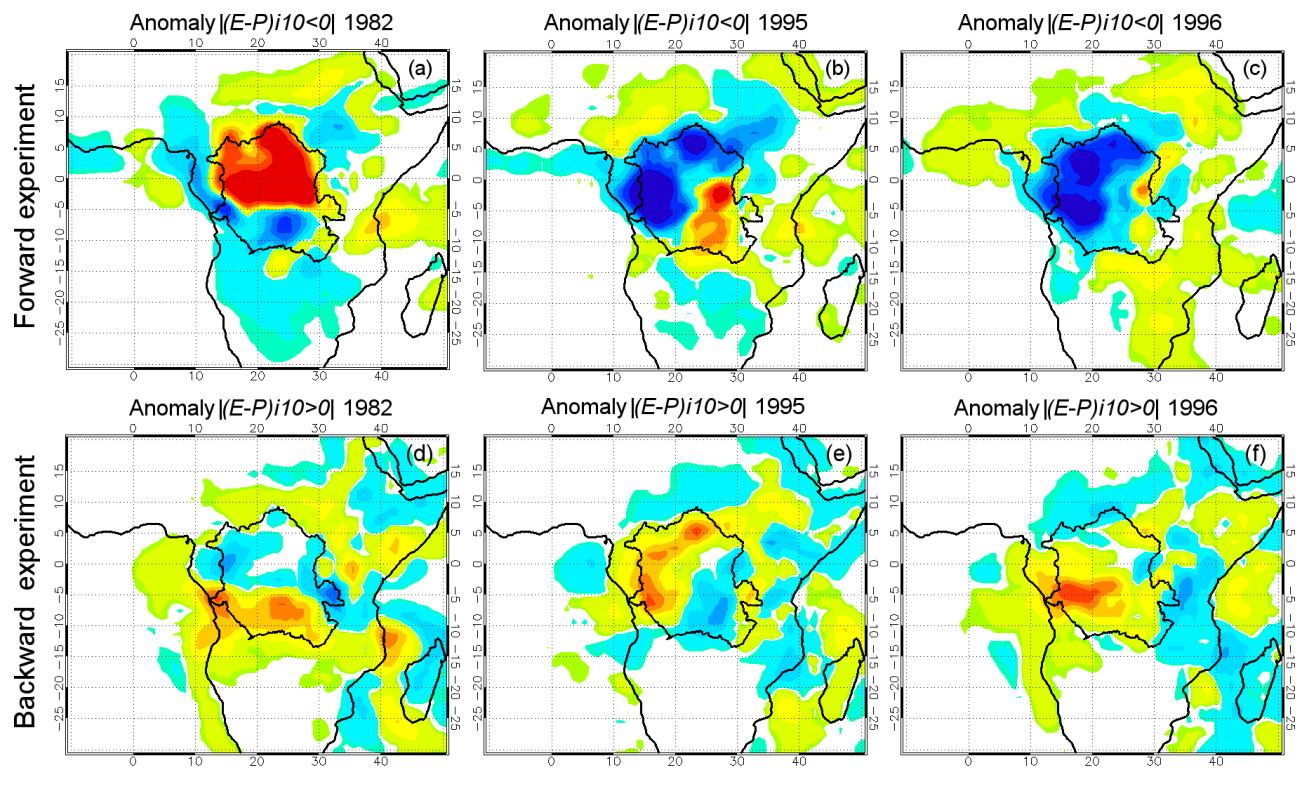

$\begin{array}{lllllllllllllllll}-3 & -2 & -1.5 & -1 & -0.5 & -0.1 & -0.05 & 0.05 & 0.1 & 0.5 & 1 & 1.5 & 2 & 3 & \left(\mathrm{~mm} \mathrm{day}^{-1}\right)\end{array}$

Figure 14. Anomaly of the $|(E-P) i 10<0|\left(\mathrm{mm} \mathrm{day}^{-1}\right)$ integrated forward from the Congo River basin in 1982 (severe wet year, a), 1995 (severe dry year, b), and 1996 (extreme dry year, c). Anomaly of the $|(E-P) i 10>0|\left(\mathrm{mm} \mathrm{day}^{-1}\right)$ integrated backward from the Congo River basin in 1982 (severe wet year, d), 1995 (severe dry year, e), and 1996 (extreme dry year, f).

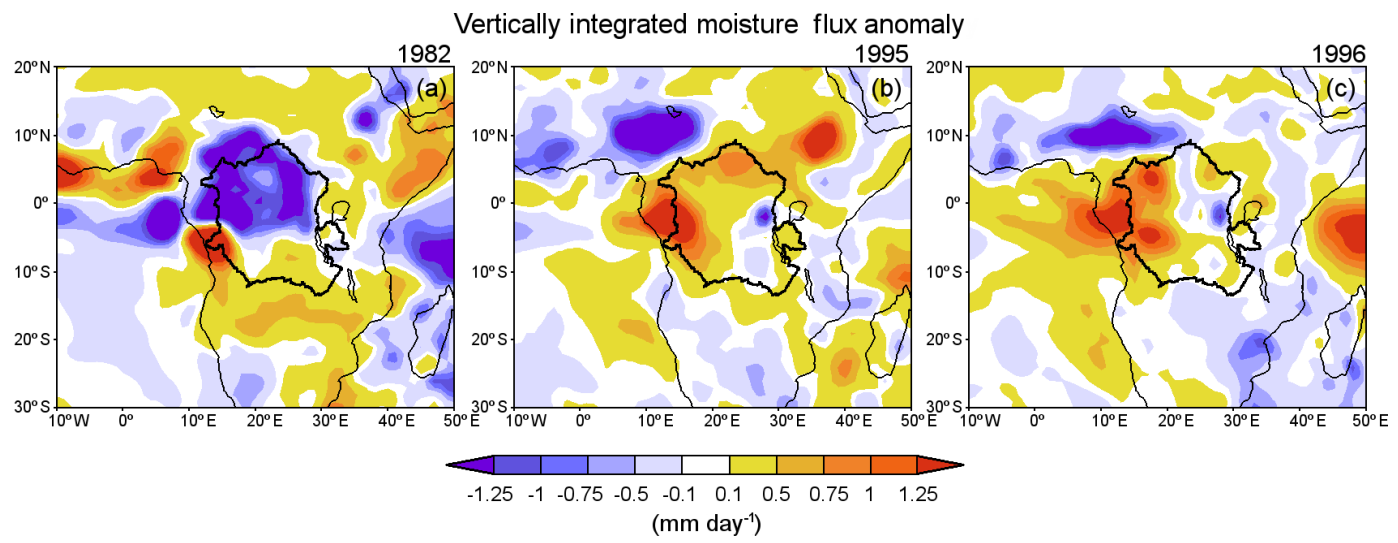

Figure 15. Anomaly of the vertically integrated moisture flux (VIMF) in 1982 (severe wet year, a), 1995 (severe dry year, b), and 1996 (extreme dry year, c).

from the CRB, respectively, are not homogenous over the CRB itself. In fact, 1982 and 1995 exhibit a relocation of regional sources and sinks of moisture in the basin. This result confirms that research on the hydrological cycle should not be developed for the entire basin, which matches Matsuyama et al. (1994). These authors argued that seasonal changes in the water budget throughout the CRB can be recognised as a combination of those in the evergreen forest and southern deciduous forest regions, but the regional characteristics of the water budget in the basin cannot be explained by studying the entire basin.

\section{Conclusions}

The most important climatological moisture sources for the Congo River basin were identified by using the Lagrangian model FLEXPART for a 31-year dataset (1980-2010). The precipitation, runoff, and river discharge at the Kinshasa gauging station were assessed. The mean annual precipitation pattern in the CRB confirmed a north-south dipole that is associated with the annual migration of the ITCZ. On average, the maximum rainfall occurs between October and April, while minima are observed in June and July, which are always in good correlation with the runoff and Congo River discharge; in particular, the monthly discharge values 
have the best correlation $(r=0.66)$ with the precipitation, exhibiting a lag of 1 month, which is the time required to pass before the runoff can be considered freshwater in the Congo River. The backward tracking of air masses revealed that the CRB receives humidity from both hemispheres. Four annual-scale oceanic moisture sources were identified in the Atlantic Ocean, the Indian Ocean, and the Red Sea, while the continent contains four sources that surround the CRB alongside the basin itself, which acts as its own moisture source. The importance of each source in the contribution from moisture to precipitation over the CRB confirms the main role of the CRB in the negative $(E-P)$ budgets over the basin itself, which represent more than $50 \%$ of the total moisture loss over the basin from all sources. Hence, local recycling processes are very important, as noted by other authors. Other important sources that provide moisture to the CRB are the tropical Atlantic Ocean (O3) and the continental region to the east of the target area (C4). At the same time, the source $\mathrm{O} 1$ in the Red Sea, despite its high evaporation rate, is considered the least efficient source for providing humidity to the basin. The efficiency of the sources that provide moisture to the CRB depends on the evaporation rate and influences the amount of water vapour that is transported to the basin, making the sources more or less effective in terms of precipitation over the CRB. Indeed, the spatial variability in the $(E-P) i 10<0$ patterns over the CRB after tracking the air masses forward from all the sources confirmed the link between the geographical location of the sources and the location of the greatest moisture sinks over the basin, which are associated with atmospheric circulation. These patterns showed a good spatial correlation with the precipitation distribution over the basin and demonstrated the ability of FLEXPART to reproduce the temporal and spatial variability in the precipitation over the CRB.

The roles of the sources that provide moisture during years with extreme and severe conditions confirmed the key role of the CRB in modulating the water balance within itself. During wet (dry) years, the contribution of moisture $((E-P) i 10<0)$ from the CRB to precipitation over itself increased (decreased). On average, the water balance in the atmosphere over the CRB was not homogenous in these years, indicating a distinct role within itself. This result confirmed that research on the hydrological cycle should not be developed for the entire basin as a whole. The vertically integrated moisture flux divergence inhibited the precipitation during dry years, when moisture uptake $((E-P) i 10>0)$ was enhanced, which suggests moisture contribution from the CRB to remote regions, an issue to be investigated in future works. The moisture source roles for the sub-basins of the CRB should be determined to better understand the complex nature of the hydrological feedback mechanisms in the Congo River basin.

These results will support further studies to address the role of the CRB's moisture sources during climate extremes such as flooding, droughts, and extreme river discharge in this basin. One important aspect for consideration in future research is related to the possible influence of modes of climate variability (such as the El Niño-Southern Oscillation or the Madden-Julian Oscillation) on the modulation of moisture transport from these sources to the CRB.

Data availability. The ERA-Interim datasets are freely available at https://www.ecmwf.int/. The precipitation and potential evapotranspiration data from CRU TS v3.23 (Harris et al., 2014) can be downloaded at http://www.cru.uea.ac.uk/data. The land evaporation data from GLEAM model (Miralles et al., 2011) are available from http://www.gleam.eu upon request, while the ocean evaporation from OAFLUX (Yu et al., 2008) can be downloaded at http://oaflux.whoi.edu. The river discharge datasets must be requested from the Global Runoff Data Centre (http://www.bafg. de/GRDC/EN/01_GRDC/grdc_node.html). The model FLEXPART (Stohl and James, 2004, 2005) can be freely downloaded (https: //www.flexpart.eu/) and utilized. For FLEXPART results, please contact Raquel Nieto (rnieto@uvigo.es).

Competing interests. The authors declare that they have no conflict of interest.

Special issue statement. The 8th EGU Leonardo Conference: From evaporation to precipitation: the atmospheric moisture transport SI statement: This article is part of the special issue "The 8th EGU Leonardo Conference: From evaporation to precipitation: the atmospheric moisture transport". It is a result of the 8th EGU Leonardo Conference, Ourense, Spain, 25-27 October 2016.

Acknowledgements. This work was developed at EPhysLab (UVIGO-CSIC Associated Unit). Thanks for the funding by the Spanish government and FEDER via the SETH (CGL201460849-JIN) project. Rogert Sorí would like to acknowledge the grant from the Xunta of Galicia, Spain, in support of his doctoral research work. Raquel Nieto also acknowledges the support that was provided by CNPq grant 314734/2014-7 from the Brazilian government. We also thank the IMDROFLOOD project financed by the Water Works 2014 co-funded call of the European Commission.

Edited by: Ricardo Trigo

Reviewed by: two anonymous referees

\section{References}

Abdulaziz, S.: Annual and Seasonal Mean Net Evaporation Rates of the Red Sea Water during Jan 1958-Dec 2007, MSc thesis, University of Bergen, 2012.

Alemaw, B. F.: Hydrological Modeling of Large Drainage Basins Using a GIS-Based Hybrid Atmospheric and Terrestrial Water Balance (HATWAB) Model, Journal of Water Resource and Protection, 4, 516-522, 2012. 
Alsdorf, D., Beighley, E., Laraque, A., Lee, H., Tshimanga, R., O'Loughlin, F., Mahé, G., Dinga, B., Moukandi, G., and Spencer, R. G. M.: Opportunities for hydrologic research in the Congo Basin, Rev. Geophys., 54, 378-409, https://doi.org/10.1002/2016RG000517, 2016.

Betbeder, J., Gond, V., Frappart, F., Baghdadi, N. N., Briant, G., and Bartholomé, E.: Mapping of Central Africa Forested Wetlands Using Remote Sensing, IEEE J. Sel. Top. Appl., 7, 531542,2014

Beyene, T., Ludwig, F., and Franssen, W.: The potential consequences of climate change in the hydrology regime of the Congo River Basin, in: Climate Change Scenarios for the Congo Basin, edited by: Haensler, A., Jacob, D., Kabat, P., and Ludwig, F., Climate Service Centre Report No. 11, Hamburg, Germany, 2013.

Bosilovich, M. G. and Schubert, S. D.: Precipitation recycling over the central United States diagnosed from the GEOS-1 data assimilation system, J. Hydrometeorol., 2, 26-35, 2001.

Bosilovich, M. G., Sud, Y. C., Schubert, S. D., and Walker, G. K.: Numerical simulation of the large-scale North American monsoon water sources, J. Geophys. Res., 108, 8614, https://doi.org/10.1029/2002JD003095, 2003.

Bower, A. S. and Farrar, J. T.: Air-Sea Interaction and Horizontal Circulation in the Red Sea, in: The Red Sea, edited by: Rasul, N. M. A. and Stewart, I. C. F., Springer Berlin Heidelberg, 329-342, 2015.

Boyer, J. F., Dieulin, C., Rouche, N., Cres, A., Servat, E., Paturel, J. E., and Mahé, G.: SIEREM: an environmental information system for water resources, Climate Variability and Change Hydrological Impacts, Proceedings of the Fifth FRIEND World Conference held at Havana, Cuba, 27 November-1 December 2006, IAHS Publ. 308, 2006.

Broxton, P. D., Zeng, X., Sulla-Menashe, D., and Troch, P. A.: A Global Land Cover Climatology Using MODIS Data, J. Appl. Meteor. Climatol., 53, 1593-1605, 2014.

Bultot, F.: Atlas climatique du bassin congolais. Deuxième partie: les composantes du bilan d'eau; Institut National pour l'Etude Agronomique du Congo (INEAC), Hors série, 150 pp., 1971.

Burde, G. I., Gandush, C., and Bayarjargal, Y.: Bulk recycling models with incomplete vertical mixing, Part II: precipitation recycling in the Amazon Basin, J. Climate, 19, 1473-1489, 2006.

Bricquet, J. P.: Les écoulements du Congo a Brazzaville et la spatialisation des apports, Grands bassins fluviaux, Paris, 22-24 Novembre, 27-38, 1993.

Bricquet, J. P.: Les écoulements du Congo à Brazzaville et la spatialisation des apports, Grands Bassins Fluviaux Périatlantiques: Congo, Niger, Amazone, Actes du colloque PEGI-INSU-CNRSORSTOM du 22 au 24 Novembre 1993, Orstom, Paris, 27-38, 1995.

Camberlin, P., Janicot, S., and Poccard, I.: Seasonality and atmospheric dynamics of the teleconnection between african rainfall and tropical sea-surface temperature: Atlantic vs. Enso, Int. J. Climatol., 21, 973-1005, https://doi.org/10.1002/joc.673, 2001.

CARPE: The Forests of the Congo Basin: A Preliminary Assessment, Central African Regional Program for the Environment, 34 pp., available at: http://carpe.umd.edu/Documents/ 2005/focb_aprelimassess_en.pdf, 2005.

Castillo, R., Nieto, R., Drumond, A., and Gimeno, L.: Estimating the Temporal Domain when the Discount of the Net Evaporation Term Affects the Resulting Net Precipitation Pattern in the Mois- ture Budget Using a 3-D Lagrangian Approach, PLoS ONE, 9 , e99046, https://doi.org/10.1371/journal.pone.0099046, 2014.

Chen, B., Xu, X. D., Yang, S., and Zhang, W.: On the origin and destination of atmospheric moisture and air mass over the Tibetan Plateau, Theor. Appl. Climatol., 110, 423-435, https://doi.org/10.1007/s00704-012-0641-y, 2012.

Chishugi, J. B.: Hydrological modelling of the Congo River basin: a soil-water balance approach, MSc thesis, University of Botswana, 2008.

Cohen, A. S., Soreghan, M. J., and Scholz, C. A.: Estimating the age of formation of lakes: an example from Lake Tanganyika East African Rift system, Geology, 21, 511-514, 1993.

COLA: The Center for Ocean-Land-Atmosphere Studies, available at: http://cola.gmu.edu/wcr/river/basins.html, last access: 2 February 2017.

Coulter, G. W.: Lake Tanganyika and Its Life, Oxford Univ. Press, New York, 1991.

Dai, A.: Increasing drought under global warming in observations and models, Nature Climate Change, 3, 52-58, 2013.

Dai, A. and Trenberth, K. E.: Estimates of Freshwater Discharge from Continents: Latitudinal and Seasonal Variations, J. Hidrometeorolgy, 3, 660-687, 2002.

Dai, A., Qian, T., and Trenberth, K. E.: Changes in Continental Freshwater Discharge from 1948-2004, J. Climate, 22, 2773 2792, https://doi.org/10.1175/2008JCLI2592.1, 2008.

Dargie, G. C., Lewis, S. L., Lawson, I. T., Mitchard, E. T. A., Page, S. E., Bocko, Y. E., and Ifo, S. A.: Age, extent and carbon storage of the central Congo Basin peatland complex, Nature, 542, 8690, 2017.

Dee, D. P. et al.: The ERA-Interim reanalysis: Configuration and performance of the data assimilation system, Q. J. Roy. Meteor. Soc., 137, 553-597, https://doi.org/10.1002/qj.828, 2011.

Dezfuli, A. K., Zaitchik, B. F., and Gnanadesikan, A.: Regional Atmospheric Circulation and Rainfall Variability in South Equatorial Africa, J. Climate, 28, 809-818, https://doi.org/10.1175/JCLI-D-14-00333.1, 2015.

Diem, J. E., Ryan, S. J., Hartter, J., and Palace, M. W.: Satellitebased rainfall data reveal a recent drying trend in central equatorial Africa, Climatic Change, 126, 263-272, 2014.

Dirmeyer, P. A. and Brubaker, K. L.: Contrasting evaporative moisture sources during the drought of 1988 and the flood of 1993, J. Geophys. Res., 104, 19383-19397, https://doi.org/10.1029/1999JD900222, 1999.

Dirmeyer, P. A., Brubaker, K. L., and DelSole, T.: Import and export of atmospheric water vapor between nations, J. Hydrol., 365, 11 22, https://doi.org/10.1016/j.jhydrol.2008.11.016, 2009.

Dominguez, F., Kumar, P., Liang, X., and Ting, M.: Impact of atmospheric moisture storage on precipitation recycling, J. Climate, 19, 1513-1530, 2006.

Domínguez, F. and Kumar, P.: Precipitation Recycling Variability and Ecoclimatological Stability-A Study Using NARR Data. Part II: North American Monsoon Region, J. Climate, 21, 5187-5203, 2008.

Domínguez, F., Kumar, P., and Vivoni, E. R.: Precipitation Recycling Variability and Ecoclimatological Stability - A Study Using 25 NARR Data. Part II: North American Monsoon Region, J. Climate, 21, 5187-5203, https://doi.org/10.1175/2008JCLI1760.1, 2008. 
Drumond, A., Marengo, J., Ambrizzi, T., Nieto, R., Moreira, L., and Gimeno, L.: The role of the Amazon Basin moisture in the atmospheric branch of the hydrological cycle: a Lagrangian analysis, Hydrol. Earth Syst. Sci., 18, 2577-2598, https://doi.org/10.5194/hess-18-2577-2014, 2014.

Drumond, A., Nieto, R., and Gimeno, L.: A Lagrangian approach for investigating anomalies in the moisture transport during drought episodes, Cuadernos de Investigación Geográfica, 42, 113-125, https://doi.org/10.18172/cig.2925, 2016 a.

Drumond, A., Taboada, E., Nieto, R., Gimeno, L., Vicente-Serrano, S. M., and López-Moreno, J. I.: A Lagrangian analysis of the present-day sources of moisture for major ice-core sites, Earth Syst. Dynam., 7, 549-558, https://doi.org/10.5194/esd-7-5492016, 2016b.

Druyan, L. M. and Koster, R. D.: Sources of Sahel Precipitation for Simulated Drought and Rainy Seasons, J. Climate, 2, 1438-1446, 1989.

Eltahir, E. A. B.: A Soil Moisture-Rainfall Feedback Mechanism: 1. Theory and observations, Water Resour. Res., 34, 765-776, https://doi.org/10.1029/97WR03499, 1998.

Eltahir, E. A. B. and Bras, R. L.: Precipitation recycling in the Amazon basin, Q. J. Roy. Meteor. Soc., 120, 861-880, https://doi.org/10.1002/qj.49712051806, 1994.

Eltahir, E. A. B. and Bras, R. L.: Precipitation recycling, Rev. Geophys., 34, 367-378, https://doi.org/10.1029/96RG01927, 1996.

Eltahir, E. A. B. and Gong, C.: Dynamics of Wet and Dry years in West Africa, J. Climate, 9, 1030-1042, https://doi.org/10.1175/15200442(1996)009<1030:DOWADY>2.0.CO;2, 1996.

Gana, M. B. and Herbert, B.: Spatial analysis from remotely sensed observations of Congo basin of east african high land to drain water using gravity for sustainable management of low laying chad basin of central Africa, The International Archives of the Photogrammetry, Remote Sensing and Spatial Information Sciences, Volume XL-1, 2014, ISPRS Technical Commission I Symposium, 17-20 November, Denver, Colorado, USA, 2014.

Gimeno, L.: Grand challenges in atmospheric science, Front. Earth Sci., 1, 1-5, https://doi.org/10.3389/feart.2013.00001, 2013.

Gimeno, L., Drumond, A., Nieto, R., Trigo, R. M., and Stohl, A.: On the origin of continental precipitation, Geophys. Res. Lett., 37, L13804, https://doi.org/10.1029/2010GL043712, 2010.

Gimeno, L., Stohl, A., Trigo, R. M., Dominguez, F., Yoshimura, K., Yu, L., Drumond, A., Durán-Quesada, A. M., and Nieto, R.: Oceanic and terrestrial sources of continental precipitation, Rev. Geophys., 50, RG4003, https://doi.org/10.1029/2012RG000389, 2012.

Gimeno, L., Nieto, R., Drumond, A., Castillo, R., and Trigo, R.: Influence of the intensification of the major oceanic moisture sources on continental precipitation, Geophys. Res. Lett., 40, 1443-1450, https://doi.org/10.1002/grl.50338, 2013.

Haensler, A., Saeed, F., and Jacob, D.: Assessment of projected climate change signals over central Africa based on a multitude of global and regional climate projections, in: Climate Change Scenarios for the Congo Basin, edited by: Haensler, A., Jacob, D., Kabat, P., and Ludwig, F., Climate Service Centre Report No. 11, Hamburg, Germany, 2013.

Harris, I., Jones, P. D., Osborn, T. J., and Lister, D. H.: Updated high-resolution grids of monthly climatic observations
- the CRU TS3.10 Dataset, Int. J. Climatol., 34, 623-642, https://doi.org/10.1002/joc.3711, 2014.

Harrison, I. J., Brummett, R., and Stiassny M. L. J.: Congo River Basin, in: The Wetland Book, edited by: Finlayson, C. M., Milton, G. R., Prentice, R. C., and Davidson, N. C., Springer Science+Business Media Dordrecht, https://doi.org/10.1007/978-94-007-6173-5_92-1, 2016.

Hua, W., Zhou, L., Chen, H., Nicholson, S. E., Raghavendra, A., and Jiang, Y.: Possible causes of the Central Equatorial African long-term drought, Environ. Res. Lett., 11, 1-13, 2016.

Ilumbe Bayeli Is'ompona, G.: Rapport des Inventaires Multiressources a Bobangi, Kinshasa, USAID, Innovative Resources Management, 2006.

IBP (International Bussines Publications): Congo, Land Ownership and Agricultural Laws Handbook, Volume 1, Strategic Information and Regulation, Edition Updated Reprint International Business Publications, Washington, USA, 2015.

Jackson, B., Nicholson, S. E., and Klotter, D.: Mesoscale convective systems over western equatorial Africa and their relationship to largescale circulation, Mon. Weather Rev., 137, 1272-1294, https://doi.org/10.1175/2008MWR2525.1, 2009.

Kadima, E., Delvaux, D., Sebagenzi, S. N., Tack, L., and Kabeya, S. M.: Structure and geological history of the Congo Basin: an integrated interpretation of gravity, magnetic and reflection seismic data, Basin Res., 23, 499-527, 2011.

Keys, P. W., van der Ent, R. J., Gordon, L. J., Hoff, H., Nikoli, R., and Savenije, H. H. G.: Analyzing precipitationsheds to understand the vulnerability of rainfall dependent regions, Biogeosciences, 9, 733-746, https://doi.org/10.5194/bg-9-733-2012, 2012.

Keys, P. W., Barnes, E. A., van der Ent, R. J., and Gordon, L. J.: Variability of moisture recycling using a precipitationshed framework, Hydrol. Earth Syst. Sci., 18, 3937-3950, https://doi.org/10.5194/hess-18-3937-2014, 2014.

Laraque, A., Pouyaud, B., Rocchia, R., Robin, R., Chaffaut, I., Moutsambote, J. M., Maziezoula, B., Censier, C., Albouy, Y., Elenga, H., Etcheber, H., Delaune, M., Sondag, F., and Gasse, F.: Origin and function of a closed depression in equatorial humid zones: the lake Telé in the north Congo, J. Hydrol., 207, 236253, 1998.

Laraque, A., Mahé, G., Orange, D., and Marieu, B: Spatiotemporal variations in hydrological regimes within Central Africa during the XX century, J. Hydrol., 245, 104-117, 2001.

Laraque, A., Bellanger, M., Adele, G., Guebanda, S., Gulemvuga, G., Pandi, A., Paturel, J. E., Robert, A., Tathy, J. P., and Yambélé, A.: Recent evolution of Congo, Oubangui and Sangha rivers flows/Evolutions récentes des débits du Congo, de l'Oubangui et de la Sangha, Geo-Eco Trop, 37, 93-100, 2013.

Lau, K. M. and Yang, S.: Walker Circulation, in: Encyclopedia of Atmospheric Sciences, edited by: Pyle, J., Curry, J. A., and Holton, J. R., Academic Press, New York, USA, 6 pp., 2002.

Lee, H., Edward, R. B., Alsdorf, D., Jung, H. C., Shum, C. K., Duan, J., Guo, J., Yamazaki, D., and Andreadis, K.: Characterization of terrestrial water dynamics in the Congo Basin using GRACE and satellite radar altimetry, Remote Sens. Environ., 115, 3530-3538, https://doi.org/10.1016/j.rse.2011.08.015, 2011.

Lehner, B. and Grill, G.: Global river hydrography and network routing: baseline data and new approaches to study the world's large river systems, Hydrol. Process., 27, 2171-2186, 2013. 
Levine, R. C. and Turner, A. G.: Dependence of Indian monsoon rainfall on moisture fluxes across the Arabian Sea and the impact of coupled model sea surface temperature biases, Clim. Dynam., 38, 2167-2190, 2012.

Lobell, D. B., Bänziger, M., Magorokosho, C., and Vivek, B.: Nonlinear heat effects on African maize as evidenced by historical yield trials, Nature Climate Change, 1, 42-45, 2011a.

Lobell, D. B., Schlenker, W., and Costa-Roberts, J.: Climate trends and global crop production since 1980, Science, 333, 616-620, 2011b.

Mahe, G.: Modulation annuelle et fluctuations interannuelles des précipitations sur le bassin versant du Congo, Coll. PEGI/INSU/ORSTOM, Paris, 22-24, 13-26, Novembre 1993.

Mahe, G., Lienou, G., Descroix, L., Bamba, F., Paturel, J. E., Laraque, A., Meddi, M., Moukolo, N., Hbaieb, H., Adeaga, O., Dieulin, C., Kotti, F., and Khomsi, K.: The rivers of Africa: witness of climate change and human impact on the environnement, Hydrol. Process., 27, 2105-2114, 2013.

Marengo, J. A.: The characteristics and variability of the atmospheric water balance in the Amazon basin: Spatial and temporal variability, Clim. Dynam., 24, 11-22, 2005.

Marquant, B., Mosnier, A., Bodin, B., Dessard, H., Feintrenie, L., Molto, Q., Gond, V., and Bayol, N.: Importance des forêts d'afrique centrale, in: Les forêts du bassin du Congo - Forêts et changements climatiques, edited by: de Wasseige, C., Tadoum, M., Eba'a Atyi, R., et Doumenge, C., Weyrich, Belgique, 128 pp., Chapter 1, 17-36, 2015.

Masih, I., Maskey, S., Mussá, F. E. F., and Trambauer, P.: A review of droughts on the African continent: a geospatial and long-term perspective, Hydrol. Earth Syst. Sci., 18, 3635-3649, https://doi.org/10.5194/hess-18-3635-2014, 2014.

Matari, E. E.: Impacts of Congo convection on tropical Africa's circulation, rainfall and resources, MSc Thesis, University of Zululand, South Africa, 165 pp., 2002.

Materia, S., Gualdi, S., Navarra, A., and Terray, L.: The effect of Congo River freshwater discharge on Eastern Equatorial Atlantic climate variability, Clim. Dynam., 39, 2109-2125, https://doi.org/10.1007/s00382-012-1514-x, 2012.

Matsuyama, H., Oki, T., Shinoda, M., and Masuda, K.: The seasonal change of the water budget in the Congo River Basin, J. Meteorol. Soc. Jpn., 72, 281-299, 1994.

McKee, T., Doesken, N., and Kleist, J.: The relationship of drought frequency and duration to time scales, Eighth Conference on Applied Climatology, 17-22 January, Anaheim, California, 1993.

Misra, V., Pantina, P., Chan, S. C., and DiNapoli, S.: A comparative study of the Indian summer monsoon hydroclimate and its variations in three reanalyses, Clim. Dynam., 39, 1149-1168, https://doi.org/10.1007/s00382-012-1319-y, 2012.

Miralles, D. G., Holmes, T. R. H., De Jeu, R. A. M., Gash, J. H., Meesters, A. G. C. A., and Dolman, A. J.: Global land-surface evaporation estimated from satellite-based observations, Hydrol. Earth Syst. Sci., 15, 453-469, https://doi.org/10.5194/hess-15453-2011, 2011.

Nicholson, S. E.: On the factors modulating the intensity of the tropical rainbelt over West Africa, Int. J. Climatol., 29, 673-689, https://doi.org/10.1002/joc.1702, 2009.

Nicholson, S. E. and Grist, J. P.: The seasonal evolution of the atmospheric circulation over West Africa and Equatorial Africa, J. Climate, 16, 1013-1030, 2003.
Nieto, R., Gimeno, L., and Trigo, R. M.: A Lagrangian identification of major sources of Sahel moisture, Geophys. Res. Lett., 33, L18707, https://doi.org/10.1029/2006GL027232, 2006.

Nieto, R., Gallego, D., Trigo, R. M., Ribera, P., and Gimeno, L.: Dynamic identification of moisture sources in the Orinoco basin in equatorial South America, Hydrol. Sci. J., 53, 602-617, 2008.

Nlom, J. H.: The Economic Value of Congo Basin Protected Areas Goods and Services, J. Sustainable Development, 4, 130-142, 2011.

Numaguti, A.: Origin and recycling processes of precipitating water over the Eurasian continent: Experiments using an atmospheric general circulation model, J. Geophys. Res., 104, 1957-1972, 1999.

Olivry, J. C., Bricquet, J. P., and Mahé, G.: Vers un appauvrissement durable des ressources en eau de l'Afrique humide?, in: Hydrology of Warm Humid Regions, edited by: Gladwell, J. S., Proc. Symp. Yokohama, Japon, July 1993, 67-78, IAHS Publ. 216, IAHS Press, Wallingford, UK, 1993.

Orange, D., Wesselink, A., Mahé, G., and Feizouré, C. T.: The effects of climate changes on river baseflow and aquifer storage in Central Africa, in: Sustainability of Water Resources Under Increasing Uncertainty, edited by: Rosbjerg, D., Boutayeb, N.E., Gustard, A., Kundzewicz, Z. W., and Rasmussen, P. F., IAHS Publ., 240, 113-123, 1997.

Owiti, Z. and Zhu, W.: Spatial distribution of rainfall seasonality over East Africa, J. Geography and Regional Planning, 5, 409421, https://doi.org/10.5897/JGRP12.027, 2012.

Pathak, A., Ghosh, S., and Kumar, P.: Precipitation recycling in the Indian subcontinent during summer monsoon, J. Hydrometeor., 15, 2050-2066, https://doi.org/10.1175/JHM-D-13-0172.1, 2014.

Pathak, A., Ghosh, S., Martínez, J. A., Domínguez, F., and Kumar, P.: Role of Oceanic and Land Moisture Sources and Transport in the Seasonal and Interannual Variability of Summer Monsoon in India, J. Climate, 30, 1839-1859, https://doi.org/10.1175/JCLID-16-0156.1, 2017.

Peixoto, J. P. and Oort, A. H.: Physics of Climate, AIP-Press, New York, NY, Springer Verlag, New York Press, 1992.

Pokhrel, S., Rahaman, H., Parekh, A., Saha, S. K., Dhakate, A., Chaudhari, H. S., and Gairola, R. M.: Evaporation-precipitation variability over Indian Ocean and its assessment in NCEP Climate Forecast System (CFSv2), Clim. Dynam., 39, 2585-2608, 2012.

Pokam, W. M., Djiotang, L. A. T., and Mkankam, F. K.: Atmospheric water vapor transport and recycling in Equatorial Central Africa through NCEP/NCAR reanalysis data, Clim. Dynam., 38, 1715-1729, https://doi.org/10.1007/s00382-011-1242-7, 2012.

Potapov, P. V., Turubanova, S. A., Hansen, M. C., Adusei, B., Broich, M., Altstatt, A., Mane, L., and Justice, C. O.: Quantifying forest cover loss in Democratic Republic of the Congo, 2000-2010, with Landsat ETM+ data, Remote Sens. Environ., 122, 106-116, 2012.

Robert, M.: Le Congo physique, ed. 3, Vaillant-Carmanne, Liège, 449 pp., 1946.

Runge, J. and Nguimalet C.-R.: Physiogeographic features of the Oubangui catchment and environmental trends reflected in discharge and floods at Bangui 1911-1999 Central African Republic, Geomorphology, 70, 311-324, 2005. 
Rwetabula, J., De Smedt, F., and Rebhun, M.: Prediction of runoff and discharge in the Simiyu River (tributary of Lake Victoria, Tanzania) using the WetSpa model, Hydrol. Earth Syst. Sci. Discuss., 4, 881-908, https://doi.org/10.5194/hessd-4-881-2007, 2007.

Salih, A. A. M., Zhang, Q., and Tjernström, M.: Lagrangian tracing of Sahelian Sudan moisture sources, J. Geophys. Res.-Atmos., 120, 6793-6808, https://doi.org/10.1002/2015JD023238, 2015.

Samba, G. and Nganga, D.: Rainfall variability in CongoBrazzaville: 1932-2007, Int. J. Climatol., 32, 854-873, https://doi.org/10.1002/joc.2311, 2012.

Sadhuram, Y. and Kumar, M. R. R.: Does evaporation over the Arabian Sea play a crucial role in moisture transport across the west coast of India during an active monsoon period?, Mon. Weather Rev., 116, 307-312, https://doi.org/10.1175/15200493(1988)116<0307:DEOTAS>2.0.CO;2, 1988.

Savenije, H. H. G.: New definitions for moisture recycling and the relationship with land-use changes in the Sahel, J. Hydrol., 167, 57-78, 1995.

SCBD-CAFC (Secretariat of the Convention on Biological Diversity and Central African Forests Commission): Biodiversity and Forest Management in the Congo Basin, Montreal, 2009.

Schmitt, R. W.: The ocean component of the global water cycle, Rev. Geophys., 33, 1395-1409, https://doi.org/10.1029/95RG00184, 1995.

Sear, D. A., Armitage, P. D., and Dawson, F. H.: Groundwater dominated rivers, Hydrol. Process., 13, 255-276, 1999.

Siam, M. S., Marie-Estelle, D., and Elfatih A. B. E.: Hydrological Cycles over the Congo and Upper Blue Nile Basins: Evaluation of General Circulation Model Simulations and Reanalysis Products, J. Climate, 26, 8881-8894, 2013.

Sodemann, H., Schwierz, C., and Wernli, H.: Interannual variability of Greenland winter precipitation sources: Lagrangian moisture diagnostic and North Atlantic Oscillation influence, J. Geophys. Res., 113, D03107, https://doi.org/10.1029/2007JD008503, 2008.

Sofianos, S. S., Johns, W. E., and Murray, S. P.: Heat and freshwater budgets in the Red Sea from direct observations at Bab el Mandeb, Deep Sea Research Part II: Topical Studies in Oceanography, 49, 1323-1340, 2002.

Sorre, M.: Le climat écologique de la cuvette centrale congolaise [D'après Mr Etienne Bernard], in: Annales de Géographie, 57, 73-75, https://doi.org/10.3406/geo.1948.12165, 1948.

Stohl, A. and James, P.: A Lagrangian analysis of the atmospheric branch of the global water cycle. Part I: Method description, validation, and demonstration for the August 2002 flooding in central Europe, J. Hydrometeorol., 5, 656-678, https://doi.org/10.1175/15257541(2004)005<0656:ALAOTA>2.0.CO;2, 2004.

Stohl, A. and James, P.: A Lagrangian analysis of the atmospheric branch of the global water cycle. Part II: Moisture transports between the Earth's ocean basins and river catchments, J. Hydrometeorol., 6, 961-984, https://doi.org/10.1175/JHM470.1, 2005.

Suzuki, T.: Seasonal variation of the ITCZ and its characteristics over central Africa, Theor. Appl. Climatol., 103, 39-60, https://doi.org/10.1007/s00704-010-0276-9, 2011.

Svoboda, M., Hayes, M., and Wood, D.: Standardized Precipitation Index User Guide, World Meteorological Organization, Geneva, WMO Rp., 1090, 24 pp., 2012.
Tshimanga, R. M. and Hughes, D. A.: Climate change and impacts on the hydrology of the Congo Basin: the case of the northern sub-basins of the Oubangui and Sangha Rivers, Phys. Chem. Earth, 50-52, 72-83, 2012.

Tchatchou, B., Sonwa, D. J., Ifo, S., and Tiani, A. M.: Déforestation et dégradation des forêts dans le Bassin du Congo: État des lieux, causes actuelles et perspectives, Papier occasionnel 120, Bogor, Indonesie, CIFOR, ISBN-13: 978-602-1504-69-7, 2015.

Trenberth, K. E.: Atmospheric Moisture Recycling: Role of Advection and Local Evaporation, J. Climate, 12, 1368-1380, 1999.

Trenberth, K. E. and Guillemot, C. J.: Physical processes involved in the 1988 drought and 1993 floods in North America, J. Climate, 9, 1288-1298, 1996.

Tsalefac, M., Hiol, F. H., Mahé, G., Laraque, A., Sonwa, D., Scholte, P., Pokam, W., Haensler, A., Beyene, T., Ludwig, F., Mkankam, F. K., Djoufack, V. M., Ndjatsana, M., and Doumenge, C.: Climat de l'Afrique centrale: passé, présent et future, edited by: de Wasseige, C., Tadoum, M., Eba'a Atyi, R., and Doumenge, C., Weyrich, Belgique, 128 pp., Chapter 2, 3752, 2015.

Tshimanga, R. M.: Hydrological uncertainty analysis and scenario based streamflow modelling for the Congo River Basin, PhD Thesis, Rhodes University repository, South Africa, 2012.

van der Ent, R. J. and Savenije, H. H. G.: Length and time scales of atmospheric moisture recycling, Atmos. Chem. Phys., 11, 18531863, https://doi.org/10.5194/acp-11-1853-2011, 2011.

van der Ent, R. J., Savenije, H. H. G., Schaefli, B., and Steele-Dunne, S. C.: Origin and fate of atmospheric moisture over continents, Water Resour. Res., 46, 1-12, https://doi.org/10.1029/2010WR009127, 2010.

van der Ent, R. J., Wang-Erlandsson, L., Keys, P. W., and Savenije, H. H. G.: Contrasting roles of interception and transpiration in the hydrological cycle - Part 2: Moisture recycling, Earth Syst. Dynam., 5, 471-489, https://doi.org/10.5194/esd-5-4712014, 2014.

Vicente-Serrano, S. M., Beguería, S., and López-Moreno, J. I.: A Multiscalar Drought Index Sensitive to Global Warming: The Standardized Precipitation Evapotranspiration Index, J. Climate, 23, 1696-1718, https://doi.org/10.1175/2009JCLI2909.1, 2010.

Vicente-Serrano, S. M., López-Moreno, J. I., Santiago, B., LorenzoLacruz, J., Azorin-Molina, C., and Morán-Tejeda, E.: Accurate computation of a streamflow drought index., J. Hydrol. Eng., 17, 318-332, 2012.

Viste, E. and Sorteberg, A.: The effect of moisture transport variability on Ethiopian summer precipitation, Int. J. Climatol., 33, 3106-3123, https://doi.org/10.1002/joc.3566, 2013.

Washington, R., James, R., Pearce, H., Pokam, W. M., and Moufouma-Okia, W.: Congo Basin rainfall climatology: can we believe the climate models?, Phil. Trans. R. Soc. B., 368, https://doi.org/10.1098/rstb.2012.0296, 2013.

Wasseige, C., Marshall, M., Mahé, G., and Laraque, A.: Interactions between climate charateristics and forest, in: Les forêts du bassin du Congo - Forêts et changements climatiques, edited by: de Wasseige, C., Tadoum, M., Eba'a Atyi, R., et Doumenge, C., Weyrich, Belgique, 128 pp., Chapter 3, 53-64, 2015.

Wesselink, A. J., Orange, D., Feizouré, C. T., and Randriamiarisoa: Les régimes hydroclimatiques et hydrologiques d'un bassin versant de type tropical humide: l'Oubangui (République Centrafricaine), in: L'Hydrologie Tropicale: géoscience et outil pour 
le Développement, edited by: Chevallier, P. and Pouyaud, B., Walingford, Oxfordshire, UK, IAHS Publ., 238, 179-194, 1996.

Yu, L.: Global Variations in Oceanic Evaporation (1958-2005): The Role of the Changing Wind Speed, J. Climate, 20, 5376-5390, https://doi.org/10.1175/2007JCLI1714.1, 2007.

Yu, L., Jin, X., and Weller, R. A.: Multidecade Global Flux Datasets from the Objectively Analyzed Air-sea Fluxes (OAFlux) Project: Latent and sensible heat fluxes, ocean evaporation, and related surface meteorological variables, Woods Hole Oceanographic Institution, OAFlux Project Technical Report, OA-200801, 64 pp., Woods Hole, Massachusetts, 2008.
Žagar, N., Skok, G., and Tribbia, J.: Climatology of the ITCZ derived from ERA Interim reanalyses, J. Geophys. Res., 116, D15103, https://doi.org/10.1029/2011JD015695, 2011.

Zheng, X. and Eltahir, E. A. B.: A Soil Moisture-Rainfall Feedback Mechanism: 2. Numerical experiments, Water Resour. Res., 34, 777-785, https://doi.org/10.1029/97WR03497, 1998.

Zhou, L., Tian, Y., Myneni, R. B., Ciais, P., Saatchi, S., Liu, Y. Y., Piao, S., Chen, H., Vermote, E. F., Song, C., and Hwang, T.: Widespread decline of Congo rainforest greenness in the past decade, Nature, 509, 86-90, https://doi.org/10.1038/nature13265, 2014. 